\title{
Contrasting rift and subduction-related plagiogranites in the Jinshajiang ophiolitic mélange, southwest China, and implications for the Paleo-Tethys
}

\begin{abstract}
Jian-Wei Zi, ${ }^{1,2}$ Peter A. Cawood, ${ }^{1,3}$ Wei-Ming Fan, ${ }^{2}$ Yue-Jun Wang, ${ }^{2}$ and Eric Tohver ${ }^{1}$
Received 3 May 2011; revised 19 October 2011; accepted 26 February 2012; published 12 April 2012.

[1] The Jinshajiang ophiolitic mélange zone in southwest China represents a remnant of the eastern Paleo-Tethys Ocean. Field, geochronological and geochemical studies have identified two distinct suites of plagiogranites within the mélange, the Dongzhulin trondhjemite and Jiyidu tonalite, which represent rift and subduction settings, respectively, related to opening and closing of the ocean. SHRIMP U-Pb analysis on zircons extracted from the Dongzhulin trondhjemite yields a mean ${ }^{206} \mathrm{~Pb} /{ }^{238} \mathrm{U}$ age of $347 \pm 7 \mathrm{Ma}$. REE and isotopic characteristics suggest an origin from low pressure partial melting of an amphibolitic protolith. Highly variable Hf isotopic compositions for zircons from this body may indicate a heterogenous source involving both depleted mantle and enriched continental components. This, together with geologic relations, suggests formation near an embryonic spreading center in a continent-ocean transition setting. The Jiyidu tonalite has a U-Pb zircon age of $283 \pm 3 \mathrm{Ma}$, and geochemical data indicates high $\mathrm{Sr} / \mathrm{Y},(\mathrm{La} / \mathrm{Yb})_{N}, \mathrm{Nb} / \mathrm{Ta}$ and low $\mathrm{Y}$, and marked heavy REE depletion. These signatures suggest derivation from low degree partial melting of subducted slab at pressure high enough to stabilize garnet and rutile. A slab-melt origin is also supported by in situ Hf and $\mathrm{O}$ data for zircon that show isotopic compositions comparable with typical altered oceanic crust. Thus, the crystallization age of the Jiyidu high $\mathrm{Sr} / \mathrm{Y}$ tonalite provides a constraint for the subduction of the Jinshajiang ocean floor. The rift-related Dongzhulin trondhjemite and subduction-related Jiyidu high-Sr/Y tonalite constrain the timing and setting of opening and closing of this segment of the Paleo-Tethys Ocean.
\end{abstract}

Citation: Zi, J.-W., P. A. Cawood, W.-M. Fan, Y.-J. Wang, and E. Tohver (2012), Contrasting rift and subduction-related plagiogranites in the Jinshajiang ophiolitic mélange, southwest China, and implications for the Paleo-Tethys, Tectonics, 31, TC2012, doi:10.1029/2011TC002937.

\section{Introduction}

[2] The recognition of ophiolites as fossil slices of oceanic lithosphere has played a major role in reconstructing ancient plate boundaries [Dilek and Robinson, 2003; Dilek and Furnes, 2011]. Plagiogranite is commonly present in the plutonic section of most ophiolites, forming a volumetrically minor part of a compositionally diverse ophiolite sequence. Plagiogranite magma can form by various processes including fractionation from a basaltic source [e.g., Aldiss, 1981; Floyd et al., 1998], and partial melting of metabasaltic and amphibolitic sources [Barker and Arth, 1976; Pedersen and Malpas, 1984; Koepke et al., 2004]. The generation of plagiogranite occurs in a variety of tectonic

\footnotetext{
${ }^{1}$ School of Earth and Environment, University of Western Australia, Crawley, Western Australia, Australia.

${ }^{2}$ State Key Laboratory of Isotope Geochemistry, Guangzhou Institute of Geochemistry, Chinese Academy of Sciences, Guangzhou, China. UK.

${ }^{3}$ Department of Earth Sciences, University of St. Andrews, St. Andrews,

Copyright 2012 by the American Geophysical Union. 0278-7407/12/2011TC002937
}

settings including high temperature shear zones close to a spreading ridge or in supra-subduction zones [Floyd et al., 1998; Li and Li, 2003; Koepke et al., 2007; Bonev and Stampfli, 2009]. Plagiogranite commonly contains zircon as a primary accessory mineral and is useful in constraining age and source through $\mathrm{U}-\mathrm{Pb}$, hafnium and oxygen isotopic analysis [e.g., Samson et al., 2004; Jiang et al., 2008].

[3] Dismembered ophiolites associated with the PaleoTethyan ocean occur in N-S trending suture zones as part of the Sanjiang Orogen of southwest China (Figure 1) [Zhang et al., 1994; Zhong, 2000]. The suture zones (Lancangjiang-Changning-Menglian, Jinshajiang-Ailaoshan and Garze-Litang sutures) and adjoining magmatic belts constitute the dominant geological features of the region. Although the original ophiolite stratigraphy has been disrupted, slices displaying complete ophiolitic sequences [Dilek and Furnes, 2011] have been identified within the Jinshajiang suture zone [Mo et al., 1993; Zhang et al., 1994; Sun and Jian, 2004]. U-Pb geochronological data from the Jinshajiang ophiolites has revealed a wide age range spanning from Early Carboniferous to Permian (i.e., $\sim 343$ Ma to $~ 294 \mathrm{Ma}$ ) [Wang et al., 2000; Jian et al., 2008, 2009b]. Together with the apparent geochemical ambiguity of these rocks, this 


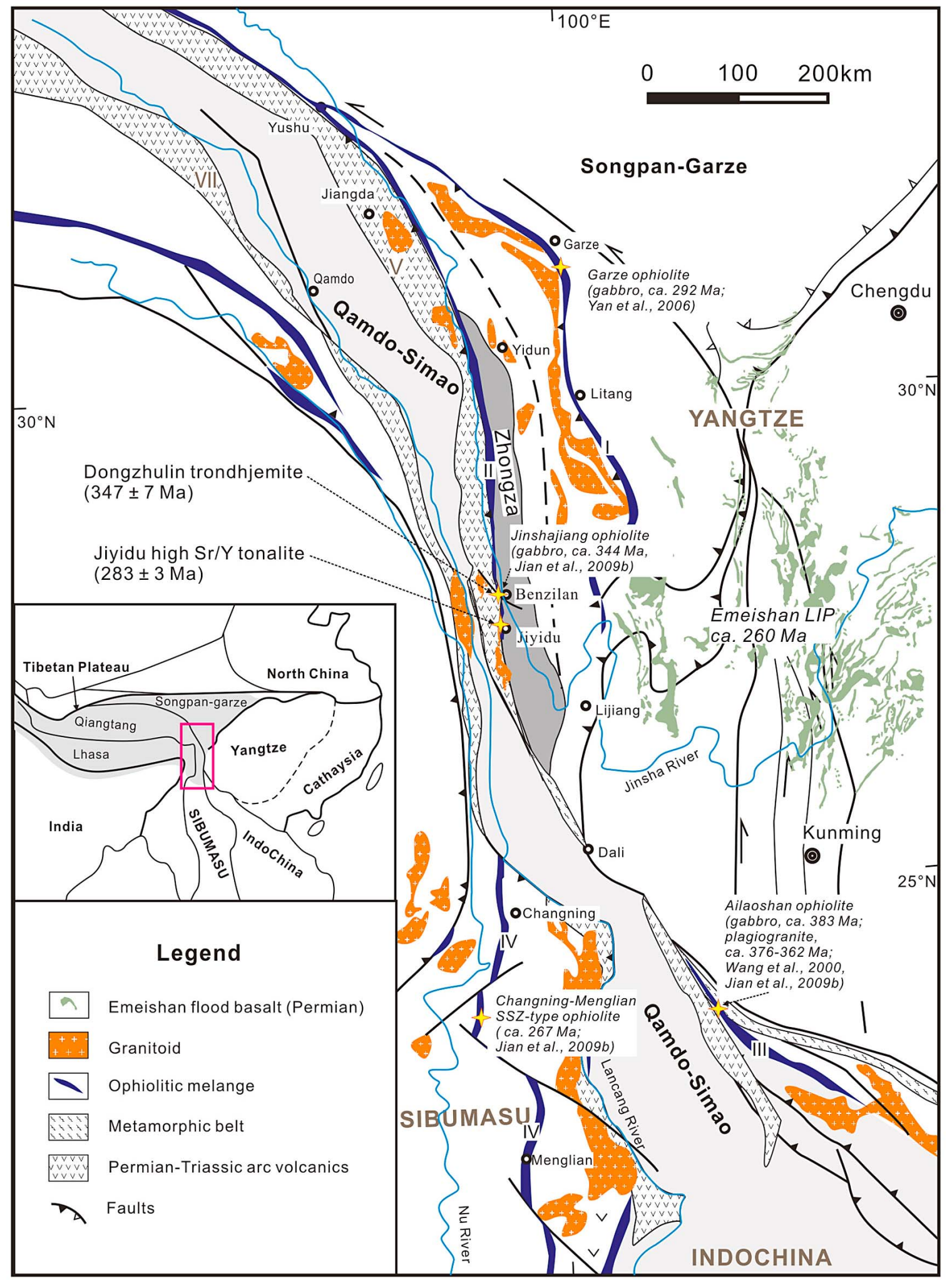

Figure 1. Sketch map highlighting principal Paleo-Tethys suture zones (ophiolitic belts) and major lithotectonic units of the Sanjiang Orogen, southwest China. Suture zones concerned in this study: I. GarzeLitang, II. Jinshajiang, III. Ailaoshan, IV. Changning-Menglian. Inset shows regional location of map area. 
geochronological uncertainty has hampered the establishment of a uniform model for the development of this segment of the Paleo-Tethys Ocean.

[4] In the present paper, we report SHRIMP zircon U-Pb geochronological, and Hf-O isotopic results, as well as whole-rock geochemical data for two suites of oceanic plagiogranite from the Jinshajiang ophiolitic mélange zone. By investigating their timing of crystallization and petrogenesis, we characterize the age and tectonic affinity of the associated Paleo-Tethyan oceanic crust. This enables regional correlations with other Paleo-Tethyan oceanic domains to be made, and allows better understanding of the evolutionary history of the Paleo-Tethys in space and time.

\section{Geological Background}

[5] The Jinshajiang ophiolite-bearing suture zone (and its southern extension) constitutes the eastern part of the so-called Sanjiang (Three Rivers) Orogen in southwest China, and marks the boundary between the Qamdo-Simao Terrane and the Yangtze Block (including the SongpanGarze and Zhongza blocks) (Figure 1). The Qamdo-Simao Terrane is thought to have an affinity to the Yangtze Block [Zhong, 2000] or to represent the northern continuation of the Indochina Block [Metcalfe, 1996b, 2006]. To the west, this terrane is bounded by the Lancangjiang-ChangningMenglian suture zone which is generally considered to represent the main Paleo-Tethys seaway, and beyond which lie the Qiangtang-Sibumasu blocks of Gondwanan affinity (Figure 1) [Wu et al., 1995; Fang et al., 1998]. Basement of this terrane is represented by high-grade metamorphic rocks (the Damenglong, Diancangshan and Shigu complexes) in which amphibolites have Mesoproterozoic Sm-Nd wholerock isochron ages [Zhong, 2000; Li et al., 2002]. The oldest exposed sedimentary rocks are Lower Ordovician metasedimentary rocks that are unconformably overlain by Middle Devonian conglomerates and shallow-marine sediments followed by Carboniferous to Permian shallow-marine, paralic and continental sediments with coal measures in places, and Lower-Middle Triassic shallow-marine clastics and carbonates [Bureau of Geology and Mineral Resources of Yunnan Province (BGMRYP), 1990].

[6] The Jinshajiang ophiolites consist of a number of blocks that occur within a N-S striking tectonic mélange zone along the Jinsha River over a distance of hundreds of kilometers (Figure 1). The ophiolite sequence shows an overall steep westerly dip. It is composed of serpentinized peridotite, deformed gabbros, mafic volcanic rocks including pillow basalts with intercalated limestone, and radiolarian cherts [Zhang et al., 1994] in a greenschist-facies matrix that comprises Permo-Carboniferous metasedimentary rocks (Gajinxueshan Group) [Wang et al., 2000], and locally a middle to late Triassic volcano-sedimentary succession [BGMRYP, 1990]. These rocks form slivers separated by cataclastic zones that show normal and right-lateral senses of shear, particularly in the serpentinized ultramafic rocks [Leloup et al., 1995]. Strongly foliated amphibolite blocks are also found in the serpentinite-matrix mélange [Jian et al., 2009a, 2009b]. The Emeishan large igneous province that extends over the western Yangtze is restricted to the area east of the Jinshajiang suture, and its major eruption pulses occurred at ca. $260 \mathrm{Ma}$ (Figure 1) [He et al., 2007; Zi et al., 2008, 2010].

[7] Cumulate peridotites, gabbros and basalts of the Jinshajiang ophiolites are characterized by low- to medium-K tholeiitic series [Mo et al., 1993; Jian et al., 2009a], LREEdepleted to -enriched patterns $\left((\mathrm{La} / \mathrm{Yb})_{N}=0.7-4.3\right.$, [Jian et al., 2009a]), age-corrected initial ${ }^{87} \mathrm{Sr} /{ }^{86} \mathrm{Sr}\left(\mathrm{I}_{\mathrm{Sr}}\right)$ of 0.7042 to 0.7060 and $\varepsilon_{\mathrm{Nd}}$ values varying from +8 to +4.4 [Zhong, 2000; Wei et al., 2003; Xu and Castillo, 2004]. They are different from subduction-related magmas in showing no depletions in $\mathrm{Nb}$ or any other HFSE. These geochemical features are interpreted to be derived from a predominantly normal-MORB source and the Jinshajiang ophiolites represent fragments of the Paleo-Tethys Ocean crust [Mo et al., 1994; Xu and Castillo, 2004; Jian et al., 2009a]. Radiogenic isotope dating on different components from the ophiolites records a broad range of apparent ages spanning from the early Carboniferous to Permian. An gabbro-anorthosite association and an amphibole gabbro have yielded zircon $\mathrm{U}-\mathrm{Pb}$ ages ranging from $\sim 338 \mathrm{Ma}$ [Jian et al., 2008] to $\sim 294 \mathrm{Ma}$ [Wang et al., 2000]. More recently, a coarse-grained gabbro from the Jinshajiang ophiolite gave an U-Pb age of $343 \pm 3 \mathrm{Ma}$, taken as an estimation of the ophiolite formation age [Jian et al., 2009b]. Final suturing of the Jinshajiang ocean appears to have occurred in Early to Middle Triassic, as indicated by regional Late Permian to Triassic disconformities [BGMRYP, 1990] and Late Permian limestone, which is the youngest exotic component embedded in the ophiolitic mélange [Sun et al., 1999]. Early Triassic deformation of the Paleozoic sequences [Zhong, 2000], and Early to Middle Triassic collision-related magmatism along the suture zone [Zi et al., 2011, 2012; J.-W. Zi, Triassic collision in the Paleo-Tethys Ocean constrained by volcanic activity in SW China, submitted to Lithos, 2012] provide minimum ages for the ophiolite sequence. The ophiolitic zone is unconformably overlain by the Late Triassic molasse. Subsequent shortening and shearing of the suture zone, likely in the Tertiary, could have formed the $\mathrm{N}-\mathrm{S}$ striking dextral cataclastic zones within the suture [Leloup et al., 1995; Zhong, 2000].

\section{Geology of Ophiolitic Plagiogranites and Sample Descriptions}

\subsection{Dongzhulin Intrusion}

[8] A north-south striking, 3-4 km wide ophiolitic assemblage is exposed between Dongzhulin and Benzilan (Figures $2 \mathrm{a}$ and $2 \mathrm{~b}$ ). From east to west it consists of layered and isotropic gabbros, a tectonic mélange of mafic volcanic rocks and limestone slices, red and purple cherts, serpentinized harzburgite, anorthosite, limestone intercalated with mafic volcanic rocks, and flyschoid sandstones [Zhang et al., 1994; Zhong, 2000]. East of Benzilan, a strongly deformed, steeply dipping sequence of marble and calcsilicate schist with interbedded horizons of flattened pillow basalt, greenschist and acidic tuff, probably Permian in age, is exposed along the Jinsha River [BGMRYP, 1990]. Within the ophiolite zones, light-colored plagiogranite occurs as irregular dikes and veins that vary in thickness from a few centimeters to several meters. 

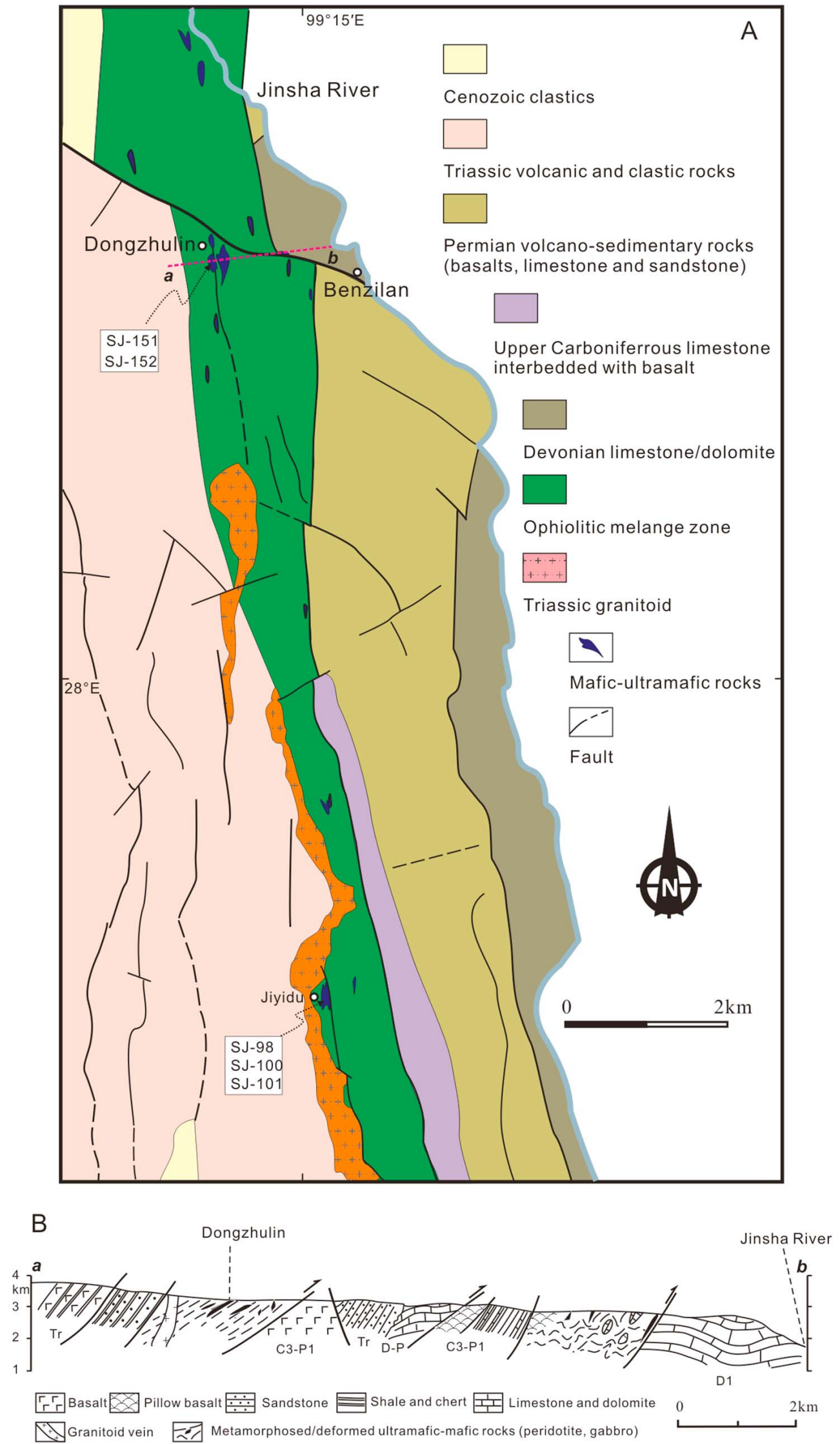

Figure 2 

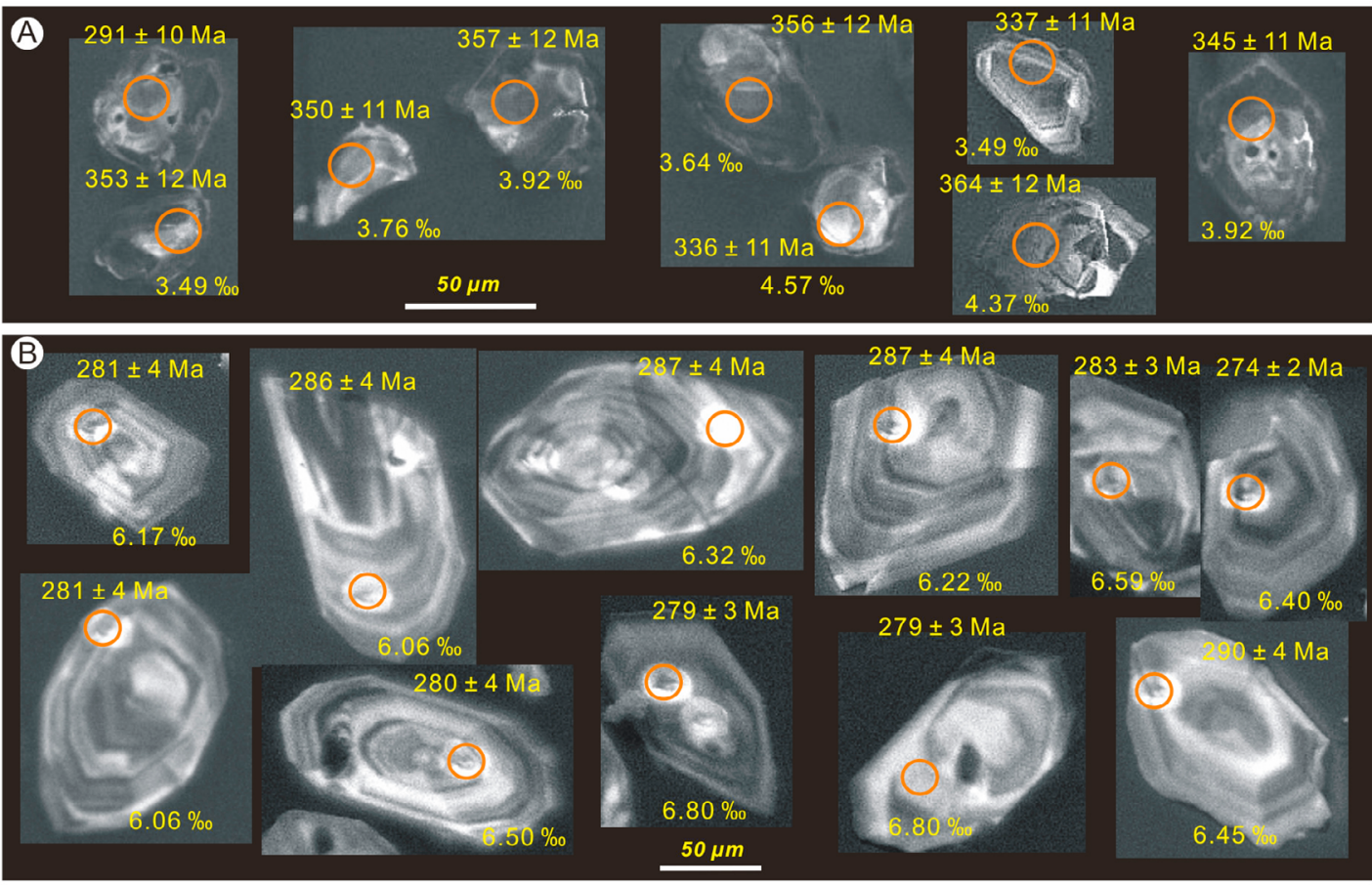

Figure 3. CL images showing morphology of typical zircons extracted from the (a) Dongzhulin and (b) Jiyidu plagiogranites. Ellipses indicate the analytical sites for U-Pb and $\mathrm{O}$ isotopes. U-Pb dates and $\delta^{18} \mathrm{O}$ values are marked near the analyzed grains.

[9] Trondhjemite samples were collected from a roadcut near Dongzhulin $\left(28^{\circ} 18.151^{\prime} \mathrm{N}, 99^{\circ} 08.966^{\prime} \mathrm{E}\right)$, where the rock occurs as a leucocratic dike intruding layered gabbro. Plagioclase and quartz are the principal modal components with apatite, titanite and zircon as accessory phases. Plagioclase consisting of oligoclase $\left(\mathrm{An}_{11-16}\right)$ is euhedral or subhedral and shows fine and compact polysynthetic twinning. Quartz forms a granophyric mosaic enclosing tabular plagioclase feldspar, and shows irregular intergrowth. Chlorite and epidote-group minerals have developed at the expense of plagioclase, but are mainly localized to cracks or mineral edges.

\subsection{Jiyidu Intrusion}

[10] A well-developed cumulate complex, consisting of metamorphosed lherzolite (serpentinite), gabbro and tonalite intrusion, is located near the Jiyidu village $\left(27^{\circ} 46.290^{\prime} \mathrm{N}\right.$, $99^{\circ} 15.278^{\prime} \mathrm{E}$ ), which represents the southern segment of the Jinshajiang ophiolitic mélange zone (Figure 2a) [Zhang et al., 1992]. The Jiyidu tonalite body, about $20 \mathrm{~m}$ wide, intrudes serpentinized lherzolite. The rock is medium-grained with a granular or granophyric texture and is composed mainly of plagioclase $\left(\mathrm{An}_{16-28}\right)$ and quartz. Plagioclase is euhedral and shows weakly positive compositional zoning. Hypidiomorphic granular quartz occurs as interstitial sub-grain filling among plagioclase crystals and shows undulatory extinction. Secondary chlorite and epidote are present in minor but variable amounts. Zircon and apatite are typical accessory minerals.

\section{Zircon U-Pb Geochronology}

\subsection{Analytical Technique}

[11] Zircon U-Pb isotopic ratios were measured on the sensitive high-resolution ion microprobe (SHRIMP II) at Curtin University following procedures outlined by Williams [1998]. Details of sample preparation and analytical procedure can be found in the auxiliary material (Text S1). ${ }^{1}$ Zircon fragments of BR266 with an age of $559 \mathrm{Ma}$ and U content of $\sim 903$ ppm [Stern, 2001], were used as the calibration standard. Errors for individual analyses are reported at $1 \sigma$ level. Unless otherwise stated, all ages reported in the text are weighted mean ${ }^{206} \mathrm{~Pb} /{ }^{238} \mathrm{U}$ ages and uncertainties are quoted at the $95 \%$ confidence level. Data processing was carried out using the Isoplot and Squid programs of Ludwig [2001a, 2001b].

\subsection{Zircon U-Pb Data and Interpretation}

\subsubsection{Dongzhulin Trondhjemite}

[12] Zircons in sample SJ-151 from the Dongzhulin trondhjemite are generally subhedral grains or crystal

${ }^{1}$ Auxiliary materials are available in the HTML. doi:10.1029/ 2011 TC002937.

Figure 2. (a) Simplified geological map of the Dongzhulin-Jiyidu segment of the Jinshajiang orogenic belt showing distribution of ophiolitic mélange and location of analyzed samples and (b) cross section showing elements of the ophiolitic mélange based on a compilation of BGMRYP [1982, 1985, 1990], Zhang et al. [1992], Wang et al. [2000], Sun and Jian [2004], and our field observations. Dashed line labeled with a, b in Figure 2a indicates location of the cross section in Figure $2 b$. 
Table 1. SHRIMP U-Pb Data of the Dongzhulin and Jiyidu Plagiogranites

\begin{tabular}{|c|c|c|c|c|c|c|c|c|c|c|c|c|c|c|}
\hline \multirow[b]{2}{*}{ Spot Number } & \multicolumn{3}{|c|}{$\begin{array}{c}\text { Concentration } \\
(\mathrm{ppm})\end{array}$} & \multirow[b]{2}{*}{$\mathrm{Th} / \mathrm{U}$} & \multicolumn{6}{|c|}{${ }^{204} \mathrm{~Pb}$ Corrected Ratio } & \multicolumn{4}{|c|}{ Calculated Apparent Age (Ma) } \\
\hline & $\mathrm{U}$ & $\mathrm{Th}$ & $\mathrm{Pb}$ & & ${ }^{207} \mathrm{~Pb} /{ }^{206} \mathrm{~Pb}$ & $\%$ err & ${ }^{207} \mathrm{~Pb} /{ }^{235} \mathrm{U}$ & $\%$ err & ${ }^{206} \mathrm{~Pb} /{ }^{238} \mathrm{U}$ & $\%$ err & ${ }^{207} \mathrm{~Pb} /{ }^{206} \mathrm{U}$ & $1 \sigma$ & ${ }^{206} \mathrm{~Pb} /{ }^{238} \mathrm{U}$ & $1 \sigma$ \\
\hline \multicolumn{15}{|c|}{ Jiyidu Tonalite (SJ-101) } \\
\hline 1 & 317 & 136 & 12 & 0.43 & 0.0524 & 3.5 & 0.321 & 3.8 & 0.0445 & 1.4 & 302 & 80 & 281 & 4 \\
\hline 2 & 424 & 140 & 16 & 0.33 & 0.0504 & 2.8 & 0.306 & 3.1 & 0.0440 & 1.3 & 212 & 65 & 278 & 4 \\
\hline 3 & 321 & 132 & 13 & 0.41 & 0.0537 & 9.1 & 0.336 & 9.2 & 0.0454 & 1.4 & 360 & 205 & 286 & 4 \\
\hline 4 & 377 & 100 & 15 & 0.26 & 0.0539 & 2.2 & 0.337 & 2.6 & 0.0454 & 1.3 & 365 & 49 & 286 & 4 \\
\hline 5 & 290 & 78 & 11 & 0.27 & 0.0504 & 4.2 & 0.301 & 4.4 & 0.0433 & 1.4 & 213 & 96 & 273 & 4 \\
\hline 6 & 308 & 94 & 12 & 0.30 & 0.0422 & 10.7 & 0.265 & 10.8 & 0.0455 & 1.6 & -214 & 268 & 287 & 4 \\
\hline 7 & 311 & 142 & 12 & 0.46 & 0.0519 & 2.5 & 0.326 & 2.8 & 0.0456 & 1.3 & 280 & 56 & 287 & 4 \\
\hline 8 & 540 & 302 & 21 & 0.56 & 0.0546 & 2.2 & 0.337 & 2.5 & 0.0448 & 1.3 & 394 & 48 & 283 & 3 \\
\hline 9 & 281 & 116 & 11 & 0.41 & 0.0539 & 3.1 & 0.342 & 3.4 & 0.0460 & 1.4 & 369 & 70 & 290 & 4 \\
\hline 10 & 528 & 141 & 20 & 0.27 & 0.0505 & 2.7 & 0.300 & 3.0 & 0.0431 & 1.3 & 217 & 63 & 272 & 3 \\
\hline 11 & 832 & 473 & 31 & 0.57 & 0.0495 & 2.0 & 0.296 & 2.3 & 0.0434 & 1.2 & 170 & 46 & 274 & 3 \\
\hline 12 & 300 & 92 & 12 & 0.31 & 0.0535 & 2.7 & 0.330 & 3.0 & 0.0447 & 1.4 & 350 & 61 & 282 & 4 \\
\hline 13 & 262 & 116 & 10 & 0.44 & 0.0500 & 3.7 & 0.306 & 4.0 & 0.0444 & 1.4 & 196 & 86 & 280 & 4 \\
\hline 14 & 1539 & 288 & 54 & 0.19 & 0.0561 & 4.7 & 0.315 & 4.9 & 0.0407 & 1.2 & 457 & 105 & 257 & 3 \\
\hline 15 & 914 & 345 & 35 & 0.38 & 0.0516 & 1.4 & 0.314 & 1.9 & 0.0442 & 1.2 & 266 & 32 & 279 & 3 \\
\hline 16 & 311 & 163 & 12 & 0.52 & 0.0507 & 3.3 & 0.301 & 3.5 & 0.0430 & 1.3 & 228 & 75 & 272 & 4 \\
\hline \multicolumn{15}{|c|}{ Dongzhulin Trondhjemite (SJ-151) } \\
\hline 1 & 1087 & 2340 & 54 & 2.15 & 0.0551 & 1.5 & 0.442 & 3.7 & 0.0581 & 3.4 & 417 & 34 & 364 & 12 \\
\hline 2 & 857 & 675 & 41 & 0.79 & 0.0534 & 1.5 & 0.411 & 3.7 & 0.0557 & 3.4 & 347 & 33 & 350 & 11 \\
\hline 3 & 2235 & 1639 & 109 & 0.73 & 0.0545 & 1.0 & 0.427 & 3.5 & 0.0568 & 3.4 & 392 & 23 & 356 & 12 \\
\hline 4 & 846 & 866 & 38 & 1.02 & 0.0520 & 1.7 & 0.379 & 3.8 & 0.0529 & 3.4 & 287 & 39 & 332 & 11 \\
\hline 5 & 252 & 252 & 12 & 1.00 & 0.0531 & 3.9 & 0.392 & 5.2 & 0.0537 & 3.4 & 331 & 88 & 337 & 11 \\
\hline 6 & 1967 & 1638 & 97 & 0.83 & 0.0536 & 0.9 & 0.424 & 3.5 & 0.0574 & 3.4 & 353 & 20 & 359 & 12 \\
\hline 7 & 831 & 792 & 38 & 0.95 & 0.0545 & 1.7 & 0.399 & 3.8 & 0.0531 & 3.4 & 392 & 38 & 334 & 11 \\
\hline 8 & 429 & 338 & 21 & 0.79 & 0.0515 & 2.9 & 0.400 & 4.4 & 0.0563 & 3.4 & 264 & 66 & 353 & 12 \\
\hline 9 & 524 & 439 & 24 & 0.84 & 0.0542 & 2.5 & 0.400 & 4.2 & 0.0535 & 3.4 & 377 & 56 & 336 & 11 \\
\hline 10 & 1489 & 1416 & 70 & 0.95 & 0.0541 & 1.7 & 0.410 & 3.8 & 0.0549 & 3.4 & 376 & 38 & 345 & 11 \\
\hline 11 & 772 & 180 & 38 & 0.23 & 0.0549 & 2.8 & 0.431 & 4.4 & 0.0569 & 3.4 & 410 & 63 & 357 & 12 \\
\hline 12 & 2683 & 1936 & 106 & 0.72 & 0.0543 & 1.1 & 0.346 & 3.6 & 0.0462 & 3.4 & 385 & 25 & 291 & 10 \\
\hline
\end{tabular}

fragments up to $\sim 70 \mu \mathrm{m}$ in length. Most zircon grains exhibit oscillatory zoning in CL images (Figure 3a). SHRIMP U-Pb results for this sample are listed in Table 1 and plotted on a concordia diagram in Figure 4a. In situ zircon analysis reveals significant variation in $\mathrm{Th}$ and $\mathrm{U}$ concentrations (180-2340 ppm and 252-2683 ppm, respectively) with high and variable $\mathrm{Th} / \mathrm{U}$ ratios ranging from 0.23 to 2.15 , indicating a magmatic origin. The concordia plot for the 12 analytical spots shows mainly concordant analyses (Figure 3a). One spot, SJ151.12, is discordant with an obviously younger age (Table 1). Excluding this analysis, the remaining eleven analyses show ${ }^{206} \mathrm{~Pb} /{ }^{23} \mathrm{U}$ ratios varying from 0.0529 to 0.0581 , corresponding to apparent ages between $332 \mathrm{Ma}$ and $364 \mathrm{Ma}$. They form a single cluster on the concordia curve and yield a weighted mean ${ }^{206} \mathrm{~Pb} /{ }^{238} \mathrm{U}$ age of $347 \pm 7$ Ma with a MSWD value of $0.99(95 \%$ confidence level). This age is taken as the best estimate of the timing of zircon crystallization within the Dongzhulin trondhjemite.

\subsubsection{Jiyidu Tonalite}

[13] Zircon crystals from sample (SJ-101) are transparent and euhedral, with most grains ranging from $\sim 60$ to $115 \mu \mathrm{m}$ in length (Figure 3b). Sixteen analyses were performed on 16 zircon grains. The analyzed zircons have intermediate $\mathrm{Th}$ and $U$ concentrations (92-473 ppm and 262-1539 ppm, respectively) and $\mathrm{Th} / \mathrm{U}$ ratio (0.19-0.57). This, together with the well-developed magmatic zoning shown in most zircon grains (Figure $3 \mathrm{~b}$ ) suggests an igneous origin, and that the measured $\mathrm{U}-\mathrm{Pb}$ ages represent the timing of crystallization of the sample. Two analytical spots are discordant (Figure 4b). Spot SJ101.6 plots to the left and above the concordia curve, which could be caused by excess common $\mathrm{Pb}$, as revealed by higher ${ }^{204} \mathrm{~Pb}$ counts, whereas its effect on ${ }^{206} \mathrm{~Pb} /{ }^{238} \mathrm{U}$ ratio seems negligible. Discordance of spot $\mathrm{SJ} 101.14$ is ascribed to radiogenic $\mathrm{Pb}$ loss during postmagmatic processes. Excluding these two spots, the remaining fourteen analyses plot on the concordia curve. Two age populations can be recognized, the major one consisting of 10 concordant analyses yields a weighted mean ${ }^{206} \mathrm{~Pb} /{ }^{238} \mathrm{U}$ age of $283 \pm 3 \mathrm{Ma}(\mathrm{MSWD}=1.03,95 \%$ confidence level). This age is slightly older than the weighted mean for all fourteen concordant analyses, which in view of the bimodal distribution, is considered a more reliable estimate of the formation age of host plagiogranite. The other four analyses ranging in ${ }^{206} \mathrm{~Pb} /{ }^{238} \mathrm{U}$ age from $271 \mathrm{Ma}$ to $274 \mathrm{Ma}$, with a weighted mean of $273 \pm 4 \mathrm{Ma}$ (MSWD = 0.13 ), may reflect post-crystallization hydrothermal perturbation on zircon U-Pb systematics (e.g., lead loss).

\section{Geochemical and Isotopic Characteristics}

[14] Whole-rock major and trace element abundances and $\mathrm{Sr}-\mathrm{Nd}$ isotopic ratios were determined at the Guangzhou Institute of Geochemistry, Chinese Academy of Sciences (GIGCAS). In situ zircon Lu-Hf isotope analyses were performed at the Hong Kong University by an ArF excimer 

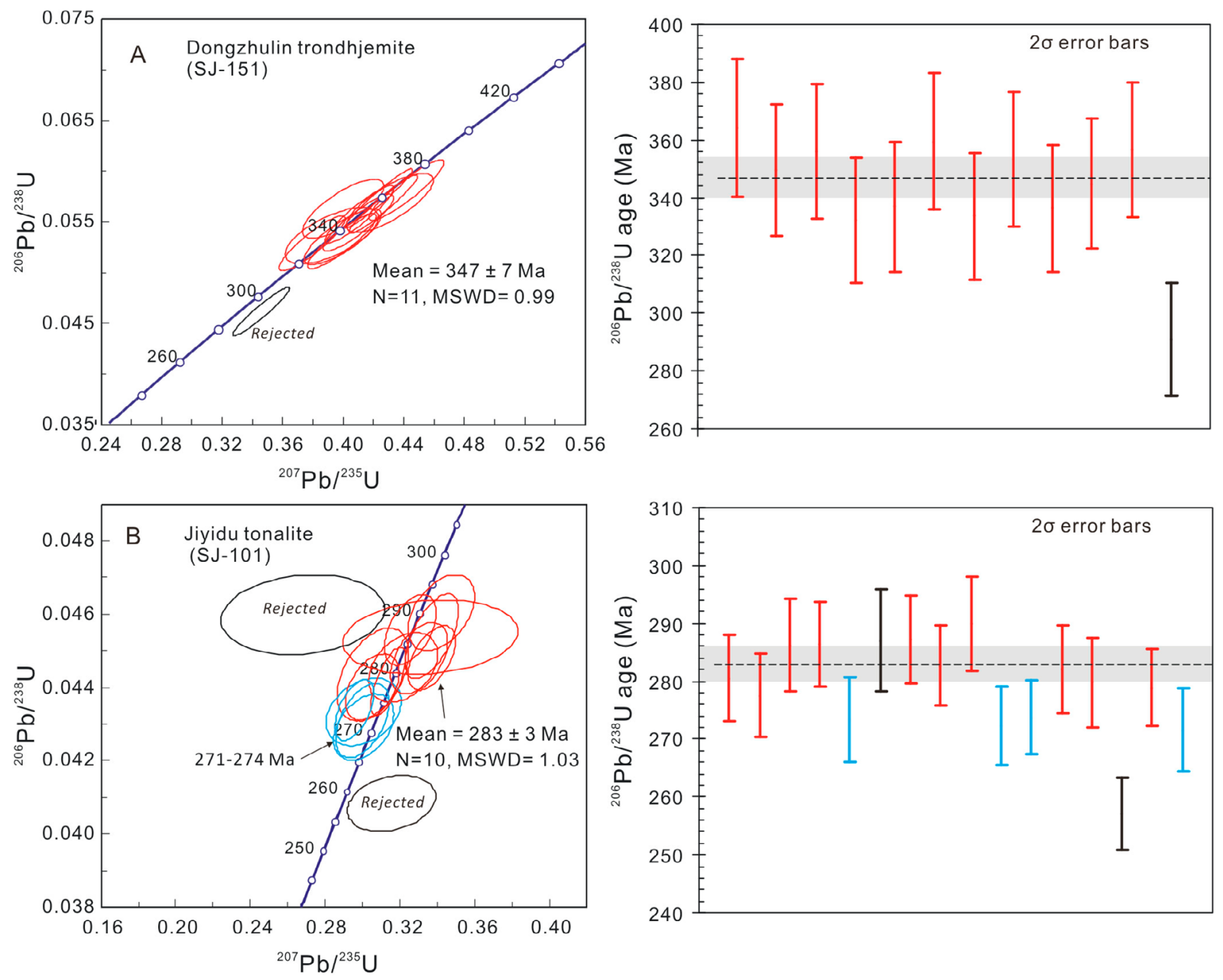

Figure 4. SHRIMP zircon U-Pb concordia diagrams for the (a) Dongzhulin trondhjemite and (b) Jiyidu high $\mathrm{Sr} / \mathrm{Y}$ tonalite from the Jinshajiang ophiolitic mélange zone, southwest China. Calculated ages and error ellipses are given at $2 \sigma, 95 \%$ confidence level.

laser ablation system, attached to a Neptune Plasma multicollector ICP-MS. Zircon oxygen isotope data were obtained using a Cameca IMS 1280 multicollector ion microprobe located at the Centre for Microscopy, Characterization and Analysis (CMCA) at the University of Western Australia. The pits generated by SHRIMP analysis were targeted when analyzing oxygen isotopes. Refer to Text S1 for detailed analytical techniques and parameters applied in analyses of major and trace elements, $\mathrm{Sr}-\mathrm{Nd}$ isotopes and zircon in situ hafnium and oxygen isotopes.

\subsection{Whole-Rock Geochemistry}

[15] Data of major and trace elements of the plagiogranites are listed in Table 2. The well-preserved igneous texture and the relatively low loss on ignition (LOI) of the samples suggest that effects of alteration and/or metamorphism are minor, with the obtained chemical data largely reflecting the primary composition of the rocks.

[16] The Dongzhulin trondhjemite has high $\mathrm{SiO}_{2}$ $(\sim 75.8 \mathrm{wt} \%)$ and $\mathrm{Na}_{2} \mathrm{O}(>5 \mathrm{wt} \%)$, and low $\mathrm{Al}_{2} \mathrm{O}_{3}(<13 \mathrm{wt}$ $\%), \mathrm{MgO}(\sim 0.69$ wt $\%), \mathrm{Fe}_{2} \mathrm{O}_{3}(\sim 1.14$ wt $\%)$ and $\mathrm{CaO}$ $(\sim 1.75 \mathrm{wt} \%)$ with metaluminous character $(\mathrm{A} / \mathrm{CNK}=0.96$ 0.98 ) and are classified as high silica-low alumina trondhjemites [Barker and Arth, 1976]. In terms of trace elements, they exhibit low $\mathrm{Rb}$ and $\mathrm{Sr}$ concentrations. Chondrite-normalized REE patterns show fractionated light $\operatorname{REE}\left((\mathrm{La} / \mathrm{Sm})_{N}=4.9-5.1\right)$ and flat heavy REE $\left((\mathrm{Gd} / \mathrm{Yb})_{N}=\right.$ 0.9-1.2) profiles, with apparent negative europium anomaly $\left(\mathrm{Eu} / \mathrm{Eu}^{*}=0.59\right)$ (Figure 5a). On a multielement spider diagram (Figure $5 \mathrm{~b}$ ) the samples normalized to primitive mantle display large-ion lithophile element (LILE) enrichment relative to high-field strength elements (HFSE). The trondhjemites are characterized by notable $\mathrm{Nb}-\mathrm{Ta}$, and $\mathrm{Ti}$ depletions and variable $\mathrm{Sr}$ anomalies, but at higher abundances relative to primitive mantle (Figure $5 \mathrm{~b}$ ).

[17] The Jiyidu samples are mildly peraluminous $(\mathrm{A} / \mathrm{CNK}=$ 1.05-1.13) with high $\mathrm{Al}_{2} \mathrm{O}_{3}$ (16.19-16.48 wt.\%), $\mathrm{Na}_{2} \mathrm{O}(5.03-$ 5.82 wt.\%) and $\mathrm{Mg \#}(68-72)$, but are low in $\mathrm{K}_{2} \mathrm{O}(0.89$ 1.63 wt.\%), $\mathrm{Fe}_{2} \mathrm{O}_{3}$ (1.74-1.99 wt.\%), $\mathrm{TiO}_{2}(0.29-0.31 \mathrm{wt} \%)$ and $\mathrm{P}_{2} \mathrm{O}_{5}(\leq 0.1 \%)$ at $\mathrm{SiO}_{2}$ contents of $69.75-70.30$ wt. $\%$ (Table 2). They have low REE abundances (total REE = 40-52 ppm), and resemble those of the other ophiolitic rocks in the suture zone [Zhang et al., 1994; Jian et al., 2009a]. When normalized to chondritic values, the samples display strongly fractionated REE patterns (Figure $5 \mathrm{c}$ ), with significant LREE enrichment relative to HREE 
Table 2. Whole-Rock Chemical and Sr-Nd Isotopic Compositions of the Dongzhulin and Jiyidu Plagiogranites

\begin{tabular}{|c|c|c|c|c|c|}
\hline Sample & SJ-98 & SJ-100 & SJ-101 & SJ-151 & SJ-152 \\
\hline $\mathrm{SiO}_{2}(\mathrm{wt} \%)$ & 67.85 & 68.73 & 68.34 & 75.80 & 75.80 \\
\hline $\mathrm{TiO}_{2}(\mathrm{wt} \%)$ & 0.28 & 0.29 & 0.30 & 0.30 & 0.31 \\
\hline $\mathrm{Al}_{2} \mathrm{O}_{3}(\mathrm{wt} \%)$ & 15.93 & 15.82 & 16.14 & 12.98 & 12.58 \\
\hline $\mathrm{Fe}_{2} \mathrm{O}_{3}(\mathrm{wt} \%)$ & 1.69 & 1.90 & 1.95 & 1.18 & 1.08 \\
\hline $\mathrm{MgO}$ (wt \%) & 1.91 & 2.05 & 1.87 & 0.55 & 0.81 \\
\hline $\mathrm{MnO}(\mathrm{wt} \%)$ & 0.04 & 0.04 & 0.03 & 0.02 & 0.01 \\
\hline $\mathrm{CaO}$ (wt \%) & 2.32 & 1.89 & 3.40 & 1.93 & 1.53 \\
\hline $\mathrm{Na}_{2} \mathrm{O}($ wt \%) & 5.66 & 5.36 & 4.92 & 5.59 & 5.55 \\
\hline $\mathrm{K}_{2} \mathrm{O}(\mathrm{wt} \%)$ & 1.51 & 1.59 & 0.87 & 0.52 & 1.16 \\
\hline $\mathrm{P}_{2} \mathrm{O}_{5}(\mathrm{wt} \%)$ & 0.09 & 0.09 & 0.09 & 0.06 & 0.06 \\
\hline LOI (wt \%) & 2.37 & 1.86 & 1.65 & 0.72 & 0.65 \\
\hline Total (wt \%) & 99.64 & 99.62 & 99.57 & 99.65 & 99.54 \\
\hline $\mathrm{V}(\mathrm{ppm})$ & 27.03 & 29.25 & 33.11 & 23.98 & 15.27 \\
\hline $\mathrm{Cr}(\mathrm{ppm})$ & 22.39 & 25.07 & 26.48 & 1.363 & 1.258 \\
\hline Mn (ppm) & 269.3 & 279.4 & 259.6 & 112.5 & 95.35 \\
\hline Co (ppm) & 6.065 & 6.276 & 7.018 & 1.75 & 3.038 \\
\hline $\mathrm{Ni}(\mathrm{ppm})$ & 24.84 & 26.95 & 29.79 & 3.778 & 2.636 \\
\hline $\mathrm{Cu}(\mathrm{ppm})$ & 2.335 & 2.719 & 4.059 & 5.356 & 37.17 \\
\hline $\mathrm{Zn}(\mathrm{ppm})$ & 38.33 & 35.95 & 29.8 & 12.53 & 19 \\
\hline $\mathrm{Ga}(\mathrm{ppm})$ & 14.11 & 14.21 & 15.16 & 11.68 & 9.637 \\
\hline Ge (ppm) & 0.74 & 0.769 & 0.791 & 1.146 & 0.883 \\
\hline $\mathrm{Rb}(\mathrm{ppm})$ & 56.07 & 52.66 & 26.48 & 11.68 & 50.5 \\
\hline $\mathrm{Sr}(\mathrm{ppm})$ & 378.8 & 374.2 & 480 & 400.9 & 109.4 \\
\hline $\mathrm{Y}(\mathrm{ppm})$ & 6.809 & 8.916 & 7.813 & 16.12 & 11.29 \\
\hline $\mathrm{Zr}(\mathrm{ppm})$ & 102.9 & 105.1 & 110.7 & 161 & 138.3 \\
\hline $\mathrm{Nb}(\mathrm{ppm})$ & 5.09 & 5.195 & 5.515 & 7.754 & 7.311 \\
\hline Cs (ppm) & 5.32 & 4.008 & 4.491 & 0.308 & 0.358 \\
\hline $\mathrm{Ba}(\mathrm{ppm})$ & 368.7 & 490.8 & 366.5 & 110.3 & 608 \\
\hline $\mathrm{La}(\mathrm{ppm})$ & 8.793 & 10.67 & 11.3 & 20.85 & 15.08 \\
\hline $\mathrm{Ce}(\mathrm{ppm})$ & 15.8 & 18.85 & 20.58 & 39.39 & 28.42 \\
\hline $\operatorname{Pr}(\mathrm{ppm})$ & 1.934 & 2.304 & 2.469 & 4.345 & 3.274 \\
\hline $\mathrm{Nd}(\mathrm{ppm})$ & 7.373 & 8.653 & 9.327 & 15.17 & 11.19 \\
\hline Sm (ppm) & 1.47 & 1.78 & 1.861 & 2.745 & 1.924 \\
\hline $\mathrm{Eu}(\mathrm{ppm})$ & 0.479 & 0.513 & 0.563 & 0.514 & 0.342 \\
\hline Gd (ppm) & 1.401 & 1.588 & 1.723 & 2.464 & 1.555 \\
\hline $\mathrm{Tb}(\mathrm{ppm})$ & 0.224 & 0.266 & 0.265 & 0.412 & 0.28 \\
\hline Dy (ppm) & 1.167 & 1.452 & 1.403 & 2.431 & 1.776 \\
\hline Ho (ppm) & 0.227 & 0.289 & 0.273 & 0.52 & 0.394 \\
\hline $\operatorname{Er}(\mathrm{ppm})$ & 0.634 & 0.799 & 0.771 & 1.545 & 1.257 \\
\hline Tm (ppm) & 0.091 & 0.118 & 0.116 & 0.247 & 0.21 \\
\hline $\mathrm{Yb}(\mathrm{ppm})$ & 0.636 & 0.803 & 0.762 & 1.729 & 1.492 \\
\hline $\mathrm{Lu}(\mathrm{ppm})$ & 0.096 & 0.128 & 0.117 & 0.275 & 0.234 \\
\hline $\mathrm{Hf}(\mathrm{ppm})$ & 2.474 & 2.618 & 2.774 & 3.753 & 3.35 \\
\hline Ta (ppm) & 0.376 & 0.488 & 0.452 & 0.655 & 0.578 \\
\hline $\mathrm{Pb}(\mathrm{ppm})$ & 7.66 & 13.03 & 9.13 & 2.412 & 1.619 \\
\hline Th (ppm) & 2.943 & 3.661 & 3.582 & 12 & 11.59 \\
\hline $\mathrm{U}(\mathrm{ppm})$ & 0.825 & 1.195 & 1.116 & 1.599 & 2.583 \\
\hline $\mathrm{Sr} / \mathrm{Y}$ & 56 & 42 & 61 & 25 & 10 \\
\hline $\mathrm{Gd} / \mathrm{Yb}_{N}$ & 1.8 & 1.6 & 1.9 & 1.2 & 0.9 \\
\hline $\mathrm{I}_{\mathrm{Sr}}$ & & 0.70495 & 0.70444 & 0.70448 & \\
\hline$\varepsilon_{\mathrm{Nd}}(\mathrm{t})$ & & & 2.18 & 3.34 & \\
\hline
\end{tabular}

$\left((\mathrm{La} / \mathrm{Yb})_{N}=9.5-10.6 ;(\mathrm{Gd} / \mathrm{Yb})_{N}=1.6-1.9\right)$, and do not show a notable $\mathrm{Eu}$ anomaly $\left(\mathrm{Eu} / \mathrm{Eu}^{*}=0.91-1.01\right)$. In NMORB normalized spidergrams, the samples show LILE enrichment and HFSE depletion, resulting in right-sloping patterns with striking $\mathrm{Sr}$ anomaly and pronounced $\mathrm{Nb}-\mathrm{Ta}$ and $\mathrm{Ti}$ anomalies (Figure 5d).

[18] Another notable feature shown by the Jiyidu samples is that they are moderately high in $\mathrm{Sr}(374-480 \mathrm{ppm})$ and low in Y (7-9 ppm), resulting in high $\mathrm{Sr} / \mathrm{Y}$ ratios of $42-61$ (Table 2). These features, in combination with high $\mathrm{SiO}_{2}$ (>56 wt.\%) and $\mathrm{Al}_{2} \mathrm{O}_{3}(>16$ wt.\%), and low $\mathrm{MgO}(<3$ wt.\%) contents, highly fractionated LREE/HREE, as well as
MORB-like isotopic compositions (see below), indicate an similarity to those of the classic adakites of Defant and Drummond [1990]. As illustrated in Figures 5c and 5d, both REE and incompatible elemental distribution patterns fall in fields defined by adakites that formed by partial melting of a subducted oceanic slab.

[19] The results of whole-rock Sr-Nd isotope analyses are given in Table 2. The initial $\mathrm{Sr}$ and $\mathrm{Nd}$ isotopic ratios were calculated based on the ages measured by SHRIMP zircon $\mathrm{U}-\mathrm{Pb}$ analyses for each sample. The Dongzhulin trondhjemite yields an initial ${ }^{87} \mathrm{Sr} /{ }^{86} \mathrm{Sr}\left(\mathrm{I}_{\mathrm{Sr}}\right)$ value of 0.70448 and $\varepsilon_{\mathrm{Nd}}(\mathrm{t})$ of 3.34 , whereas the Jiyidu samples have $\mathrm{I}_{\mathrm{Sr}}$ values ranging from 0.70444 to 0.70495 , and $\varepsilon_{\mathrm{Nd}}(\mathrm{t})$ value of 2.18 .

\subsection{Zircon in Situ Hafnium and Oxygen Isotopes}

[20] A representative sample from each of the Dongzhulin and Jiyidu plagiogranite intrusions were chosen for $\mathrm{Hf}$ and $\mathrm{O}$ isotopic analysis. Twenty analyzed zircons from the Dongzhulin trondhjemite show highly variable initial ${ }^{176} \mathrm{Hf} /{ }^{177} \mathrm{Hf}$ ratios ranging from 0.283066 to 0.282030 and $\varepsilon_{\mathrm{Hf}}(\mathrm{t})$ from +18.0 to -18.6 (Table 3 and Figures $6 \mathrm{a}$ and $6 \mathrm{~b}$ ). Seven out of twenty spots have positive $\varepsilon_{\mathrm{Hf}}(\mathrm{t})$ values and single-stage $\mathrm{Hf}$ model ages $\left(\mathrm{T}_{\mathrm{DM}}\right)$ that range from 0.25 to $0.99 \mathrm{Ga}$; the remaining 13 spots have negative $\varepsilon_{\mathrm{Hf}}(\mathrm{t})$ values and two-stage $\mathrm{Hf}$ model ages $\left(\mathrm{T}_{\mathrm{DM}}^{\mathrm{C}}\right)$ of $1.42-2.53 \mathrm{Ga}$. The total of 20 spots point to a weighted mean $\varepsilon_{\mathrm{Hf}}(\mathrm{t})$ value of $4.5 \pm 2.7(\mathrm{MSWD}=1.7,95 \%$ confidence level). Twenty zircons of the Jiyidu sample show less variable initial ${ }^{176} \mathrm{Hf} /{ }^{177} \mathrm{Hf}$ ratios ranging from 0.282910 to 0.282472 , corresponding to $\varepsilon_{\mathrm{Hf}}(\mathrm{t})$ from +11.0 to -4.5 (Table 3 and Figure 6a). All but one analysis (spot 15) have positive $\varepsilon_{\mathrm{Hf}}(\mathrm{t})$ values, and they give single-stage $\mathrm{Hf}$ model ages $\left(\mathrm{T}_{\mathrm{DM}}\right)$ from 0.48 to $0.73 \mathrm{Ga}$. All 20 analyses yield a weighted mean $\varepsilon_{\mathrm{Hf}}(\mathrm{t})$ of $8.08 \pm 0.77$ (MSWD $=1.4,95 \%$ confidence level).

[21] Zircons from the Dongzhulin trondhjemite yield $\delta^{18} \mathrm{O}$ values varying between 3.49 and $4.57 \%$ (VSMOW). Whereas zircons from Jiyidu high-Sr/Y tonalite have relatively higher $\delta^{18} \mathrm{O}$ ranging from 6.06 to $6.80 \%$ o (Table 4 and Figure 7). Thirteen analyses for this sample give a weighted mean of $6.37 \pm 0.13 \%$ (MSWD $=1.3,95 \%$ confidence level). Calculated whole rock $\delta^{18} \mathrm{O}$ values in equilibrium with zircon $\delta^{18} \mathrm{O}$ can be approximated by the recognized linear relationship: whole rock $\delta^{18} \mathrm{O}=$ zircon $\delta^{18} \mathrm{O}+$ $0.0612 *\left(w t . \% \mathrm{SiO}_{2}\right)-2.5$ [Valley et al., 2005]. For the studied samples, the zircon $\delta^{18} \mathrm{O}$ values of the Dongzhulin and Jiyidu plagiogranites yield calculated whole rock $\delta^{18} \mathrm{O}$ of 5.58-6.66\% (mean 5.98\%o) and 7.72-8.46\% (mean $8.02 \%$ ), respectively (Table 4 ).

\section{Discussion}

\subsection{Genesis of the Dongzhulin Trondhjemite}

[22] The Dongzhulin trondhjemites have initial $\mathrm{Sr}$ and $\mathrm{Nd}$ isotopic ratios analogous to that of the Paleo-Tethys mantle [Zhong, 2000; Wei et al., 2003]. The presence of high initial Hf isotopic ratios $\left(\varepsilon_{\mathrm{Hf}}(\mathrm{t})\right.$ up to 18 , Table 3 and Figure $\left.6 \mathrm{a}\right)$ for zircons from this intrusion also suggests they are derived from a depleted mantle source. Geochemical characteristics combined with field occurrence intimately associated with the Jinshajiang ophiolite complex, indicate oceanic plagiogranite affinities for the Dongzhulin body. Several models for the petrogenesis of oceanic plagiogranite have been put 

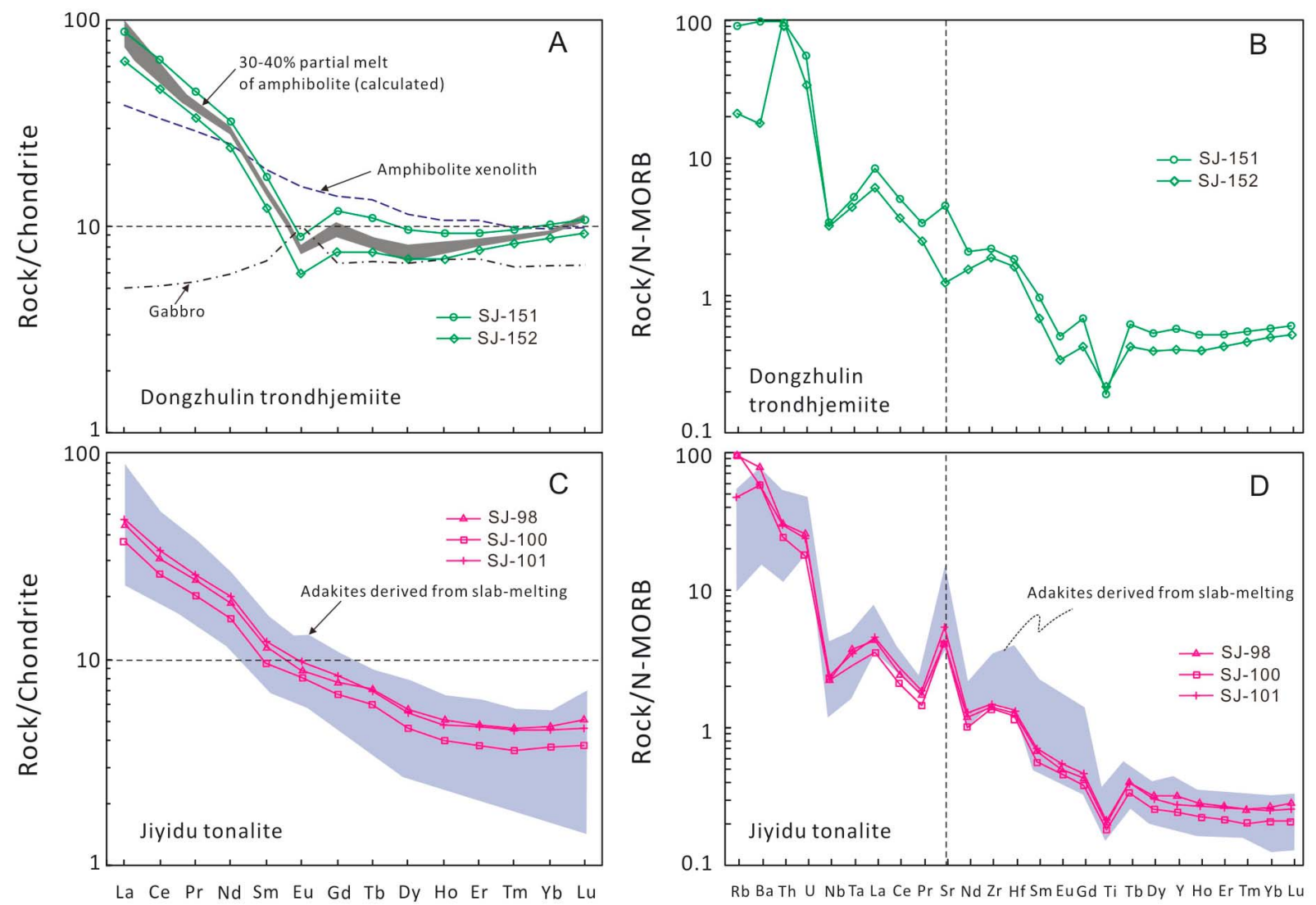

Figure 5. ( $a$ and $b$ ) Chondrite normalized REE patterns and (c and d) N-type MORB normalized spidergrams. Normalization values are from Sun and McDonough [1989]. Curves of the partial melts were calculated following batch melting equation of Shaw [1970] and using distribution coefficients of Arth [1976]. Gabbros and amphibolite xenoliths [Jian et al., 2009a] from the Jinshajiang ophiolitic assemblage were tested as two possible trondhjemite parents. The REE modeling demonstrates $30-40 \%$ partial melting of the amphibolite xenolith can generate REE patterns matching well with that of the Dongzhulin trondhjemite. Fields of slab-melting derived adakites (shaded areas) in Figures $5 \mathrm{~b}$ and $5 \mathrm{~d}$ are based on published data [Defant and Drummond, 1990; Stern and Kilian, 1996, and references therein].

forward, including (a) extreme fractionation of mid-ocean ridge basaltic melts [e.g., Aldiss, 1981; Floyd et al., 1998], (b) partial melting of hydrated basaltic/gabbroic protoliths [e.g., Barker and Arth, 1976; Pedersen and Malpas, 1984; Koepke et al., 2004], and (c) silicate immiscibility of an evolved tholeiitic liquid [Dixon and Rutherford, 1979]. The high $\mathrm{Mg} \#$ but low $\mathrm{TiO}_{2}$ of the Dongzhulin trondhjemites present a striking contrast to the majority of plagiogranites that formed through MORB differentiation or immiscibility $\left(\mathrm{Mg} \#<40, \mathrm{TiO}_{2}>1 \%\right)$ [Barker and Arth, 1976; Dixon and Rutherford, 1979; Koepke et al., 2007]. However, these features are compatible with a genesis by anatexis of basaltic sources, as experimentally demonstrated by Koepke et al. [2004]. On the other hand, LREE enrichment relative to HREE and a negative europium anomaly shown by the analyzed Dongzhulin samples (Figures $5 \mathrm{a}$ and $5 \mathrm{~b}$ ) also favor an origin from partial melting of gabbroic/basaltic rocks [e.g., Flagler and Spray, 1991; Floyd et al., 1998; Bonev and Stampfli, 2009]. This is in contrast to plagiogranites produced by low-pressure crystal fractionation of a MORB source which generally show flat/unfractionated REE patterns, subparallel to those of MORB-type parents [e.g.,
Pallister and Knight, 1981; Pedersen and Malpas, 1984; Floyd et al., 1998; Dilek and Thy, 2006].

[23] Undepleted/flat heavy REE profiles suggest that the trondhjemitic liquid were generated in a low-pressure (garnet-absent) field. Residues from partial melting containing plagioclase, hornblende (and/or pyroxene) and accessory minerals may be responsible for the high silica, low $\mathrm{Al}_{2} \mathrm{O}_{3}$, $\mathrm{TiO}_{2}$ and $\mathrm{P}_{2} \mathrm{O}_{5}$ and negative europium anomaly observed in the Dognzhulin samples. Gabbro and amphibolite were tested, respectively, as possible parents of the trondhjemite by REE-modeling partial melting. Gabbros from the Jinshajiang ophiolitic assemblage show slight depletion of light REEs (Figure 5a) [Jian et al., 2009a]. Following the batch melting equation of Shaw [1970], partial melting of the Jinshajiang gabbro with residual plagioclase and clinopyroxene can generate the negative $\mathrm{Eu}$ anomalies in the resulting melts, but fails to account for the enrichment of light REEs of the Dongzhulin trondjemite, because of the relatively flat REE patterns (except for the Eu anomaly) for both plagioclase and clinopyroxene [Arth, 1976]. Assuming the amphibolite xenolith [Jian et al., 2009a] as a starting material and using the partition coefficients of Arth [1976], the resulting melts of $30-40 \%$ batch melting leaving behind 
Table 3. Zircon Hafnium Isotopic Data of the Dongzhulin and Jiyidu Plagiogranites

\begin{tabular}{|c|c|c|c|c|c|c|c|c|}
\hline Analysis Number & ${ }^{176} \mathrm{Lu} /{ }^{177} \mathrm{Hf}$ & $\pm 2 \sigma$ & ${ }^{176} \mathrm{Yb} /{ }^{177} \mathrm{Hf}$ & $\pm 2 \sigma$ & ${ }^{176} \mathrm{Hf} /{ }^{177} \mathrm{Hf}$ & $\pm 2 \sigma$ & $\varepsilon_{\mathrm{Hf}}(\mathrm{t})$ & $\mathrm{T}_{\mathrm{DM}}^{\mathrm{C}}$ \\
\hline \multicolumn{9}{|c|}{ Jiyidu Tonalite (SJ-101) } \\
\hline 01 & 0.000871 & 0.000012 & 0.015763 & 0.002800 & 0.282891 & 0.000198 & 10.2 & 0.65 \\
\hline 02 & 0.001005 & 0.000019 & 0.022643 & 0.000439 & 0.282844 & 0.000027 & 8.5 & 0.76 \\
\hline 03 & 0.001256 & 0.000055 & 0.028299 & 0.001260 & 0.282751 & 0.000052 & 5.2 & 0.97 \\
\hline 04 & 0.001074 & 0.000053 & 0.024639 & 0.001330 & 0.282742 & 0.000056 & 4.9 & 0.99 \\
\hline 05 & 0.001116 & 0.000040 & 0.024625 & 0.000898 & 0.282841 & 0.000065 & 8.4 & 0.77 \\
\hline 06 & 0.001063 & 0.000014 & 0.023523 & 0.000322 & 0.282843 & 0.000035 & 8.5 & 0.76 \\
\hline 07 & 0.001258 & 0.000076 & 0.027218 & 0.001610 & 0.282802 & 0.000039 & 7.0 & 0.86 \\
\hline 08 & 0.001002 & 0.000018 & 0.020911 & 0.000363 & 0.282880 & 0.000025 & 9.8 & 0.68 \\
\hline 09 & 0.001250 & 0.000029 & 0.027906 & 0.000604 & 0.282749 & 0.000119 & 5.1 & 0.98 \\
\hline 10 & 0.001347 & 0.000072 & 0.027834 & 0.001590 & 0.282759 & 0.000034 & 5.4 & 0.96 \\
\hline 11 & 0.001026 & 0.000012 & 0.022346 & 0.000261 & 0.282872 & 0.000034 & 9.5 & 0.70 \\
\hline 12 & 0.001029 & 0.000008 & 0.022264 & 0.000288 & 0.282770 & 0.000095 & 5.9 & 0.93 \\
\hline 13 & 0.000844 & 0.000026 & 0.017551 & 0.000595 & 0.282807 & 0.000032 & 7.2 & 0.84 \\
\hline 14 & 0.001029 & 0.000013 & 0.022196 & 0.000294 & 0.282867 & 0.000041 & 9.3 & 0.71 \\
\hline 15 & 0.001058 & 0.000018 & 0.024149 & 0.000603 & 0.282477 & 0.000188 & -4.5 & 1.59 \\
\hline 16 & 0.001098 & 0.000015 & 0.025065 & 0.000373 & 0.282827 & 0.000032 & 7.9 & 0.80 \\
\hline 17 & 0.001137 & 0.000033 & 0.024772 & 0.000633 & 0.282836 & 0.000039 & 8.2 & 0.78 \\
\hline 18 & 0.001223 & 0.000036 & 0.025781 & 0.000798 & 0.282844 & 0.000038 & 8.5 & 0.76 \\
\hline 19 & 0.001212 & 0.000017 & 0.025387 & 0.000343 & 0.282916 & 0.000049 & 11.0 & 0.60 \\
\hline 20 & 0.001020 & 0.000012 & 0.020669 & 0.000264 & 0.282809 & 0.000048 & 7.3 & 0.84 \\
\hline \multicolumn{9}{|c|}{ Dongzhulin Trondhjemite (SJ-151) } \\
\hline 01 & 0.002372 & 0.000096 & 0.054666 & 0.002310 & 0.282544 & 0.000251 & -1.0 & 1.42 \\
\hline 02 & 0.004240 & 0.000186 & 0.098378 & 0.004580 & 0.282071 & 0.000285 & -18.2 & 2.50 \\
\hline 03 & 0.001682 & 0.000054 & 0.038665 & 0.001090 & 0.282324 & 0.000286 & -8.6 & 1.90 \\
\hline 04 & 0.004638 & 0.000222 & 0.115300 & 0.005720 & 0.282341 & 0.000215 & -8.7 & 1.91 \\
\hline 05 & 0.002235 & 0.000030 & 0.052532 & 0.000860 & 0.282923 & 0.000226 & 12.5 & 0.56 \\
\hline 06 & 0.003017 & 0.000120 & 0.076223 & 0.003180 & 0.282570 & 0.000121 & -0.2 & 1.37 \\
\hline 07 & 0.003860 & 0.000132 & 0.092508 & 0.004020 & 0.282429 & 0.000224 & -5.4 & 1.70 \\
\hline 08 & 0.003119 & 0.000115 & 0.076390 & 0.002730 & 0.283086 & 0.000203 & 18.0 & 0.20 \\
\hline 09 & 0.002522 & 0.000043 & 0.057651 & 0.001460 & 0.282539 & 0.000372 & -1.2 & 1.43 \\
\hline 10 & 0.002842 & 0.000073 & 0.068349 & 0.001760 & 0.282399 & 0.000298 & -6.2 & 1.75 \\
\hline 11 & 0.002565 & 0.000025 & 0.060265 & 0.000701 & 0.282813 & 0.000099 & 8.5 & 0.82 \\
\hline 12 & 0.004118 & 0.000291 & 0.100817 & 0.007250 & 0.282656 & 0.000111 & 2.6 & 1.19 \\
\hline 13 & 0.001642 & 0.000028 & 0.038190 & 0.001000 & 0.282490 & 0.000351 & -2.7 & 1.53 \\
\hline 14 & 0.003155 & 0.000071 & 0.074677 & 0.001940 & 0.282438 & 0.000212 & -4.9 & 1.67 \\
\hline 15 & 0.002248 & 0.000039 & 0.053705 & 0.001360 & 0.282045 & 0.000379 & -18.6 & 2.53 \\
\hline 16 & 0.002867 & 0.000180 & 0.071067 & 0.004740 & 0.282779 & 0.000070 & 7.2 & 0.90 \\
\hline 17 & 0.002338 & 0.000069 & 0.054690 & 0.001270 & 0.282575 & 0.000180 & 0.1 & 1.35 \\
\hline 18 & 0.003436 & 0.000047 & 0.079284 & 0.001250 & 0.282446 & 0.000164 & -4.7 & 1.66 \\
\hline 19 & 0.004008 & 0.000123 & 0.101792 & 0.002970 & 0.282775 & 0.000043 & 6.8 & 0.92 \\
\hline 20 & 0.003625 & 0.000118 & 0.084219 & 0.002320 & 0.282411 & 0.000385 & -6.0 & 1.74 \\
\hline
\end{tabular}

$85 \%$ plagioclase and $15 \%$ hornblende yield the REE distribution patterns matching well with that of the Dongzhulin trondhjemite (Figure 5a).

[24] The well-known resilience of zircon to Hf isotopic disturbance during post-crystallization processes makes $\mathrm{Hf}$ composition of zircon a reliable geochemical tracer to elucidate the origin of a host rock [Kinny and Maas, 2003]. Zircons from the Early Carboniferous trondhjemite show a broad range up to $\sim 30 \varepsilon$ units for a single sample, with maximum $\varepsilon_{\mathrm{Hf}}(\mathrm{t})$ equivalent to depleted mantle value (Table 3 and Figure 6a). This is consistent with a mantlederived amphibolite as its precursor. The negative shift of the $\varepsilon_{\mathrm{Hf}}(\mathrm{t})$ values might have been enhanced by incorporation of inclusions or possible xenocrystic zircons during analysis, in view of the small grain size and complicated morphology of the Dongzhulin zircons (Figure 3a). If the considerable variability (probably to a less extent) is genuine, this indicates that magmas forming the trondhjemite intrusions were heterogeneous in $\mathrm{Lu} / \mathrm{Hf}$ ratios during periods of zircon saturation (Figure 6b). The highly negative $\varepsilon_{\mathrm{Hf}}(\mathrm{t})$ values require an additional component of nonradiogenic Hf to be present, which is likely to be a continental contaminant [Griffin et al., 2000]. Zircons crystallizing from magmas formed by variable degrees of interaction of the depleted source with the extra low Lu/Hf component tend to show within-sample Hf isotope variations in excess of analytical error [Griffin et al., 2002; Hawkesworth and Kemp, 2006]. We therefore suggest that the magmas from which the trondhjemite zircons crystallized were derived from depleted mantle-type sources, and developed negative $\varepsilon_{\mathrm{Hf}}(\mathrm{t})$ through reaction with ancient continental materials, which also accounts for the LILE enrichment and negative $\mathrm{Nb}$ and $\mathrm{Ti}$ anomalies (Figure $5 \mathrm{c}$ ) and the presence of the Proterozoic Hf model ages $\left(\mathrm{T}_{\mathrm{DM}}^{\mathrm{C}}=\right.$ 1.42-2.53 Ga; Table 3 and Figure 6a).

\subsection{Genesis of the Jiyidu High-Sr/Y Tonalite}

[25] The Jiyidu tonalite samples share some similarities with the Dongzhulin trondhjemite in terms of geochemical characteristics such as high $\mathrm{Na}_{2} \mathrm{O}$-low $\mathrm{K}_{2} \mathrm{O}$, HSFE-depletion and presence of MORB-like $\mathrm{Sr}-\mathrm{Nd}$ isotopic compositions. However, they are distinguished by high $\mathrm{Al}_{2} \mathrm{O}_{3}, \mathrm{Sr}(374$ $480 \mathrm{ppm}$, positive $\mathrm{Sr}$ anomaly in spidergram) and $\mathrm{Sr} / \mathrm{Y}$ ratios 

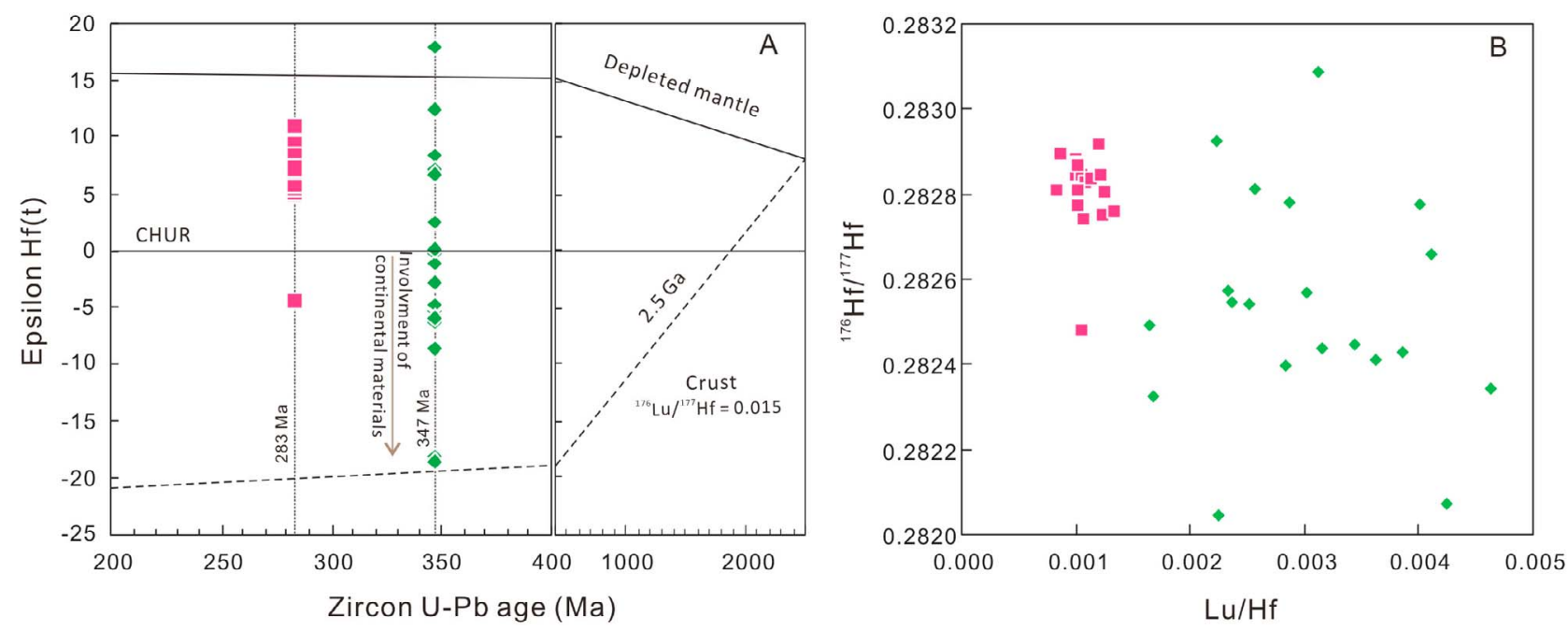

Figure 6. Hf isotope composition of the ophiolitic plagiogranites from the Jinshajiang zone showing highly heterogenous Hf compositions for the Early Carboniferous Dongzhulin trondhjemite (diamonds) and predominantly positive $\varepsilon_{\mathrm{Hf}}(\mathrm{t})$ values for the Early Permian Jiyidu high $\mathrm{Sr} / \mathrm{Y}$ tonalite (squares).

(42-61), and depletion of heavy REEs (Table 2 and Figure 5c). Moreover, they have elevated $\mathrm{SiO}_{2}(67.85-$ $68.73 \%)$ and $\mathrm{Na}_{2} \mathrm{O} / \mathrm{K}_{2} \mathrm{O}(3.36-5.63)$, but low $\mathrm{MgO}(1.87-$ $2.05 \%)$ and $\mathrm{TiO}_{2}(0.29-0.31 \%)$. All these characteristics are reminiscent of those of the adakites (sensu stricto) of Defant and Drummond [1990] or the high-silica adakites of Martin et al. [2005].

[26] Primitive mantle normalized multielement diagrams for the Jiyidu high $\mathrm{Sr} / \mathrm{Y}$ tonalites show LILE-enrichment and HFSE-depletion profiles and consequential high LILE/ HFSE ratios, characteristic of island arc-related petrogenesis (Figure 5d). The Jiyidu samples have relatively high Hf contents and $(\mathrm{Hf} / \mathrm{Nd})_{N}$ ratio, both pertinent to proto-arc magma genesis [Pearce et al., 1999]. Their moderately high $\mathrm{Sr}$ abundance, as shown by the Sr spike, and absence of negative Eu anomaly in the spidergram, preclude substantial plagioclase in the residual phase. The negative $\mathrm{Nb}$ and $\mathrm{Ta}$ anomalies, and the elevated $\mathrm{Nb} / \mathrm{Ta}$ ratios (11-14) likely reflect the presence of rutile as a high pressure phase [Green, 1995].

[27] Elevation of $\mathrm{Sr} / \mathrm{Y}$ and depletion of the heavy REEs, can be achieved via different processes including deep fractionation of a garnet-dominated assemblage, partial melting of subducted oceanic slab or mafic lower crust with abundant residual garnet or interaction of felsic melts with the mantle [e.g., Petford and Gallagher, 2001; Garrison and Davidson, 2003; Wang et al., 2005; Macpherson et al., 2006; Richards and Kerrich, 2007]. High pressure fractional crystallization of garnet may account for the depletion of heavy REEs and high $\mathrm{Sr} / \mathrm{Y}$, but fails to explain the enrichment of light REEs. Melting of mafic lower crust may be the source for high-Sr/Y rocks in some intracontinental or arc settings in response to significant thickening of crusts [e.g., Wang et al., 2005; Schwartz et al., 2011], but this is generally restricted to the late stages of a collisional orogenesis, and such a source is inconsistent with the high $\mathrm{Mg \#}$ and $\mathrm{Na}_{2} \mathrm{O} / \mathrm{K}_{2} \mathrm{O}$ of the Jiyidu high $\mathrm{Sr} / \mathrm{Y}$ tonalite. Geochemical modeling has revealed that the classic slab melting model provides the most plausible explanation for genesis of high- silica adakites [Martin et al., 2005; Moyen, 2009], which reinforces the prevailing views relating generation of sensu adakite to the subduction of oceanic lithosphere [Defant and Drummond, 1990; Peacock et al., 1994; Drummond et al., 1996; Stern and Kilian, 1996; Smithies and Champion, 2000; Bourdon et al., 2002]. Striking geochemical similarities between the Jiyidu high-Sr/Y tonalite and the high-silica adakites, make a slab-melting model also applicable for genesis of the former. Moreover, the studied samples from Jiyidu display uniformly low $\mathrm{I}_{\mathrm{Sr}}$ of $\sim 0.7045$ and positive $\varepsilon_{\mathrm{Nd}}(\mathrm{t})$ of 2.18 (Table 2) similar to the $\mathrm{Sr}-\mathrm{Nd}$ isotopic values

Table 4. Oxygen Isotopic Composition of the Dongzhulin and Jiyidu Plagiogranites

\begin{tabular}{cccc}
\hline $\begin{array}{c}\text { Analysis } \\
\text { Number }\end{array}$ & Zircon $\delta^{18} \mathrm{O}(\%)$ & $\pm 2 \sigma$ & $\begin{array}{c}\text { Calculated Melt } \\
\delta^{18} \mathrm{O}(\%)\end{array}$ \\
\hline & \multicolumn{3}{c}{ Jiyidu Tonalite } \\
(SJ-101) & \\
01 & 6.06 & 0.19 & 7.73 \\
02 & 6.17 & 0.18 & 7.84 \\
03 & 6.06 & 0.22 & 7.72 \\
04 & 6.23 & 0.19 & 7.89 \\
05 & 6.32 & 0.21 & 7.98 \\
06 & 6.22 & 0.18 & 7.88 \\
07 & 6.59 & 0.20 & 8.25 \\
08 & 6.45 & 0.21 & 8.11 \\
09 & 6.24 & 0.19 & 7.90 \\
10 & 6.40 & 0.15 & 8.07 \\
11 & 6.50 & 0.17 & 8.16 \\
12 & 6.80 & 0.21 & 8.46 \\
13 & 6.58 & 0.15 & 8.24 \\
& & & \\
& & & \\
01 & Dongzhulin Trondhjemite (SJ-151) & 6.46 \\
02 & 4.37 & 0.20 & 5.58 \\
03 & 3.49 & 0.19 & 6.01 \\
04 & 3.92 & 0.19 & 6.66 \\
05 & 4.57 & 0.17 & 5.73 \\
06 & 3.64 & 0.20 & 6.01 \\
07 & 3.92 & 0.17 & 5.58 \\
08 & 3.49 & 0.23 & 5.85 \\
\hline
\end{tabular}




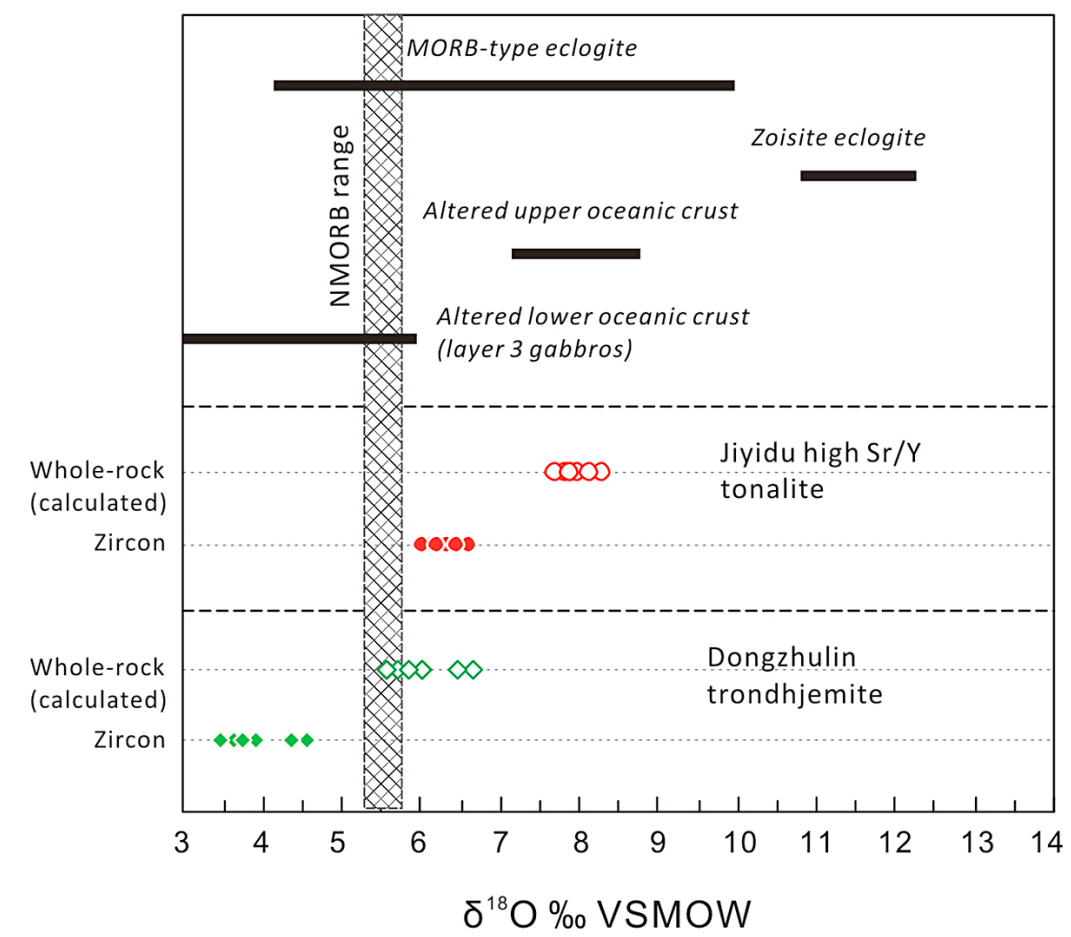

Figure 7. Oxygen isotope compositions of the Dongzhulin and Jiyidu plagiogranites compared to fresh MORB [Eiler et al., 2000], low-temperature (low-T) altered oceanic crust [Gregory and Taylor, 1981; Cocker et al., 1982], MORB-type and zoisite eclogites (garnet values) from Halama et al. [2011]. Whole-rock $\delta^{18} \mathrm{O}$ is calculated according to the relation: whole rock $\delta^{18} \mathrm{O} \approx$ zircon $\delta^{18} \mathrm{O}+0.0612 *(\mathrm{wt} . \%$ $\left.\mathrm{SiO}_{2}\right)-2.5$ [Valley et al., 2005].

for the Jinshajiang MORBs [Xu and Castillo, 2004], consistent with a slab-melt origin.

[28] Further compelling evidence in favor of a slab-melt origin derive from zircon $\mathrm{Hf}$ and $\mathrm{O}$ isotopic systematics. The predominantly positive $\varepsilon_{\mathrm{Hf}}(\mathrm{t})$ values (4.9-11, except for one spot -4.5 ; Table 3 and Figure 6 ) for zircons from Jiyidu high-Sr/Y tonalite indicate a variably depleted precursor, compatible with a derivation from partial melting of subducted oceanic slab. The mantle-like $\varepsilon_{\mathrm{Hf}}(\mathrm{t})$ together with the relatively low $\mathrm{I}_{\mathrm{Sr}}$ values rule out appreciable involvement of subducted sediments into the adakitic melts, consistent with trace element modeling which shows that low-degree ( $\sim 20 \%$ ) partial melting of an eclogitic MORB (see Stern and Kilian [1996] for parameters and distribution coefficients used in the partial melting modeling) with little contribution from sediments can produce the Sr-Y signature observed in the Jiyidu tonalite (Figures $8 \mathrm{a}$ and 8b). High $\mathrm{Mg \#}$ and $\mathrm{Ni}$ and $\mathrm{Cr}$ contents are similar to those of the highsilica adakites [Martin et al., 2005], but clearly higher than in experimental liquids obtained by basalt or amphibolite melting [Rapp and Watson, 1995]. These differences are generally interpreted to result from interaction of the slab derived melts with mantle peridotite as they rise through the overlying mantle wedge [Yogodzinski et al., 1995; Stern and Kilian, 1996; Rapp et al., 1999; Smithies and Champion, 2000].

[29] The measured zircon $\delta^{18} \mathrm{O}$ values for the Jiyidu high$\mathrm{Sr} / \mathrm{Y}$ tonalite range from 6.06 to $6.80 \%$ with a weighted mean of $6.37 \pm 0.13 \%$. The calculated $\delta^{18} \mathrm{O}$ values for the silicate melts in equilibrium with these zircons vary between 7.72\%o and 8.46\% (Table 4 and Figure 7), higher than the normal mantle value of $~ 5.5 \%$ [Eiler et al., 2000; Valley, 2003]. This is consistent with the observation that slabmelt derived adakitic magmas as a group are ${ }^{18} \mathrm{O}$ enriched compared to fresh MORBs and typical arc basalts, as documented by modern adakites in Fiji and Kamchatka [Bindeman et al., 2005]. Such a deviation can be interpreted as inheritance from high- $\delta{ }^{18} \mathrm{O}$ altered basaltic upper oceanic crust with or without contribution of sediments [McCulloch et al., 1981; Stakes et al., 1984; Staudigel et al., 1995; Bindeman et al., 2005]. The whole-rock $\delta^{18} \mathrm{O}$ values for the Jiyidu high-Sr/Y tonalite fall within the range typically observed for the basaltic sections of ophiolites [Gregory and Taylor, 1981; Cocker et al., 1982; Putlitz et al., 2000; Eiler, 2001; Stakes and Taylor, 2003], and in the range for MORBtype eclogites from the Raspas Complex, Ecuador (Figure 7) [Halama et al., 2011]. Furthermore, these values overlap with those of the altered (lower greenschist facies) upper oceanic crust $\left(\delta^{18} \mathrm{O}=7.1-8.8 \%\right.$ ) recorded for the Macquarie Island ophiolite (Figure 7) [Cocker et al., 1982], in accordance with the above contention suggesting such rocks as magma source.

\subsection{Geodynamic Significances and Implications for the Paleo-Tethys at Jinshajiang Segment}

\subsubsection{Geodynamic Significances Inferred From Geochemical and Geochronologic Data}

[30] Geochemical data suggests the petrogenesis of the Jiyidu tonalite and Dongzhulin trondhjemite were dominated by partial melting rather than differentiation of MORB-type 

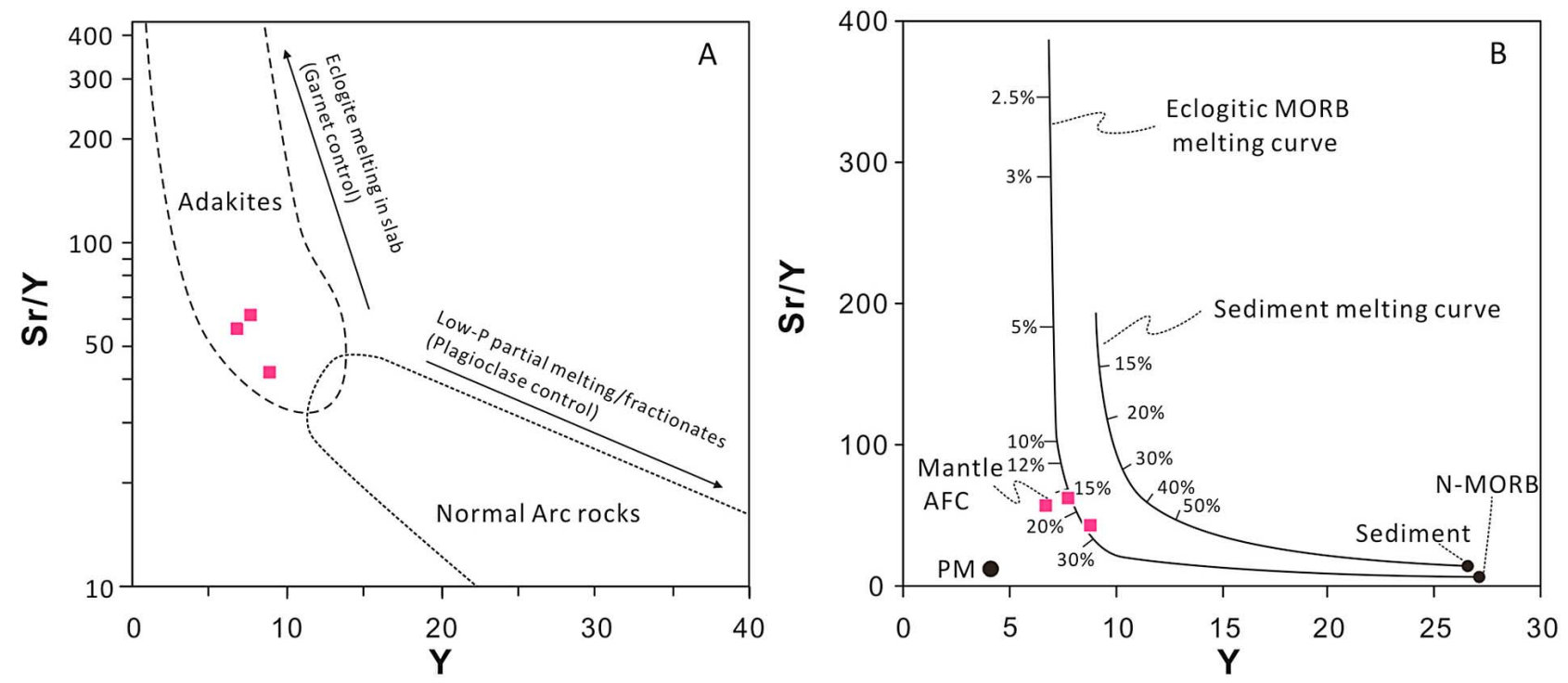

Figure 8. (a) Diagnostic trace element differences between slab-derived adakites and normal arc rocks (modified after Defant and Drummond [1990]). Adakites form by melting at high pressure in equilibrium with garnet and so have low Y contents and high $\mathrm{Sr} / \mathrm{Y}$ ratios, relative to the normal arc rocks formed at lower pressure in equilibrium with plagioclase. (b) $\mathrm{Sr} / \mathrm{Y}$ versus $\mathrm{Y}$ diagram showing that low-degree ( $\sim 20 \%$ ) partial melting of eclogitic MORB can produce the Sr-Y signatures observed in the Jiyidu tonalite. The component values, melting curves of eclogitic MORB and sediment and mantle AFC trend are after Stern and Kilian [1996].

sources. But the differences between the two bodies in REE distribution patterns along with multiple isotopic features indicate distinct tectonic settings.

[31] The Dongzhulin body probably originated from hydrous partial melting of an altered gabbroic/amphibolitic protolith. The Sr-Nd isotopic data $\left(\mathrm{I}_{\mathrm{Sr}}=0.70448, \varepsilon_{\mathrm{Nd}}(\mathrm{t})=\right.$ 3.34) are permissive of mantle-derived protoliths. The ca. 443-401 Ma amphibolites with low-Ti tholeiitic composition [Jian et al., 2009a, 2009b] that are entrapped within the Jinshajiang ophiolite are a plausible candidate for such a source. Anatexis of amphibolite in high-temperature shear zones in proximity to a spreading center has been demonstrated to be a feasible mechanism generating plagiogranite liquid [e.g., Flagler and Spray, 1991]. This is consistent with the in situ zircon oxygen isotopic data which show low $\delta^{18} \mathrm{O}$ values (3.49-4.57\%, Table 4) for the Dongzhulin trondhjemite relative to normal mantle $(\sim 5.3 \%$ [Valley, 2003]) and suggests that the rocks or the amphibolite precursors might have experienced high-temperature hydrothermal alteration [Gregory and Taylor, 1981; Cocker et al., 1982], in response to heat input from a spreading center. The significant zircon $\mathrm{Hf}$ isotopic variation exhibited by the Dongzhulin trondhjemite (Table 3 and Figures 6a and 6b) suggests a highly heterogenous source, which may reflect involvement of an enriched source (i.e., continental materials) into depleted melts. Together, the above observations imply that the oceanic crust preserved in the Dongzhulin ophiolite was generated in the ocean-continent transition setting in which both enriched continental materials and depleted mantle source were readily involved. Some basalt and diabase samples from the Jinshajiang ophiolite exhibit an overall EMORB affinity [Mo et al., 1994], compatible with the above scenarios. If this inference is correct, the ca. $347 \mathrm{Ma}$ igneous age obtained from the Dongzhulin trondhjemite provides an older age for the onset of Jinshajiang seafloor spreading.

[32] Identification of high $\mathrm{Sr} / \mathrm{Y}$ and MORB-like Sr-Hf-O isotopic signatures (highly resemble those of the classic adakites, [Defant and Drummond, 1990; Moyen, 2009]) on the Jiyidu tonalite body suggests an oceanic subduction setting. The $283 \pm 3$ Ma SHRIMP zircon U-Pb age yielded from the high $\mathrm{Sr} / \mathrm{Y}$ tonalite provides a minimum estimate for the age of the oceanic crust produced by the intraoceanic subduction within the Jinshajiang branch. This age is comparable with an Alaska-type zoned mafic-ultramafic complex occurring in the southern Lancangjiang zone, which is believed to represent a plutonic arc produced by the early stage westward subduction of the branch ocean beneath the Qamdo-Simao Terrane [Zhang et al., 1994], and yields U-Pb zircon age of ca. $286 \mathrm{Ma}$ [Jian et al., 2009b], representing the oldest arc related magmatism recorded in the zone.

[33] Our new zircon ages of the plagiogranite samples from Dongzhulin and Jiyidu show a $\sim 60$ Ma age difference. No single ophiolite with a single tectonic pathway for its igneous evolution displays such a large age gap [Dilek and Robinson, 2003]. Therefore, the plagiogranites and the ultramafic-mafic associations within the Jinshajiang tectonic zone likely represent different geodynamic settings. In light of the recent ophiolite classification scheme of Dilek and Furnes [2011], the $347 \pm 7 \mathrm{Ma}$ trondhjemite and associated ultramafic-mafic rocks formed part of a continental margin ophiolite at an Ocean-Continent Transition (OCT) during the rift-drift tectonics of the Jinshajiang ocean basin, whereas the $283 \pm 3 \mathrm{Ma}$ high $\mathrm{Sr} / \mathrm{Y}$ tonalite and associated 


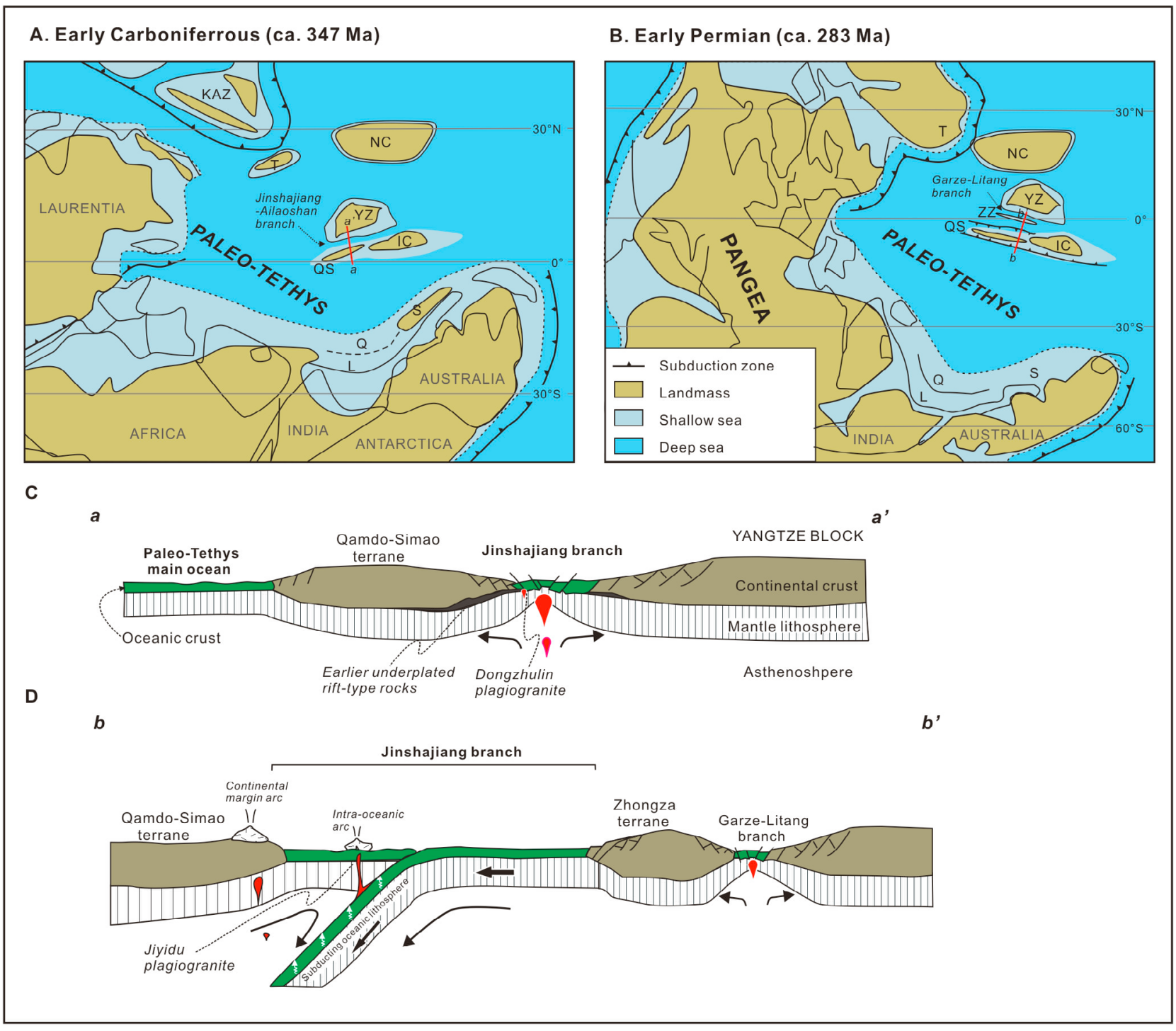

Figure 9. Paleogeographic reconstructions of the Tethyan region placing the study area in a regional context in (a) Early Carboniferous and (b) Early Permian [after Metcalfe, 2006]. YZ = Yangtze; T = Tarim; IC = Indochina; NC = North China; $\mathrm{QS}=$ Qamdo-Simao; $\mathrm{S}=$ Sibumasu; $\mathrm{Q}=$ Qiangtang; $\mathrm{L}=$ Lhasa; ZZ $=$ Zhongza. Cartoons (not to scale) illustrating opening and subduction scenarios of the Paleo-Tethyan Jinshajiang Ocean with respect to formations of the two types of oceanic plagiogranites. (c) Formation of the ca. $347 \mathrm{Ma}$ Dongzhulin trondhjemite during opening of the Jinshajiang oceanic basin in the Early Carboniferous, was preceded by lithospheric extension and rift magmatism over the western Yangtze; (d) Formation of the ca. 283 Ma Jiyidu high-Sr/Y tonalite indicates an ongoing subduction of the Jinshajiang oceanic lithosphere in the Early Permian, and birth of an intraoceanic island arc. Positions of transects are marked as red line in Figures $9 \mathrm{a}$ and $9 \mathrm{~b}$.

ultramafic-mafic rocks may have formed part of a volcanic arc ophiolite after the inception of an intraoceanic subduction zone within the Jinshajiang ocean basin. These contrasting environments were tectonically telescoped during orogeny as the Jinshajiang ocean basin closed and the bounding continents collided resulting in the formation of an ophiolitic mélange zone [Dilek and Flower, 2003; Festa et al., 2010].

\subsubsection{Implications for the Paleo-Tethys}

[34] Paleogeographic reconstruction suggests that the late Paleozoic to early Mesozoic Paleo-Tethys in Southeast Asia was characterized by an archipelago of arcs or continental ribbons separating multiple seaways (Figures $9 a$ and 9b), a configuration analogous to the present-day southwest Pacific [e.g., Metcalfe, 1996a; Pan et al., 1997; Zhong, 2000; Pan et al., 2003; Metcalfe, 2006].

[35] The Proterozoic metamorphic rocks, pre-Early Devonian sedimentary cover and the Middle Devonian conglomerate in the Qamdo-Simao Terrane lithologically resemble those of the Yangtze and suggest a pre-middle Devonian linkage between the two blocks [BGMRYP, 1990; Zhong, 2000; Sun and Jian, 2004]. Existence of early Late 
Paleozoic extension-related magmatism [Mo et al., 1993; Jian et al., 2009a] in the Jinshajiang suture zone suggests that opening and spreading of the Jinshajiang branch ocean was preceded by intracontinental extension and rifting over the western Yangtze margin, probably in the middle to late Devonian [Feng et al., 1999], with the rift succession comprising Late Devonian conodont and radiolarian-bearing limestone and turbidite sequences [Sun and Jian, 2004]. The presence of zircon grains yielding apparently older ages (ca. $375 \mathrm{Ma}$, [Jian et al., 2008]) against the predominant PermoCarboniferous age obtained from gabbro-anorthosite components of the Jinshajiang ophiolite may also be attributed to an early phase of continental rift-related magmatism in the Late Devonian. Our new SHRIMP U-Pb age (347 $\pm 7 \mathrm{Ma}$ ) from the Dongzhulin trondhjemite, along with an age of ca. $343 \mathrm{Ma}$ for a cumulate gabbro [Jian et al., 2009b] are the oldest precise igneous ages for the Jinshajiang ophiolite. This constrains the onset of spreading of the Paleo-Tethyan Jinshajiang branch to be of Early Carboniferous age or earlier (Figures 9a and 9c).

[36] Given that the Jinshajiang and Ailaoshan belts (see Figure 1) have comparable lithological assemblages and deformation-metamorphic history, it is suggested that ophiolites occurred in both belts are contiguous and represent the same ocean basin (Figure 9a) [Metcalfe, 1996a; Zhang et al., 1996; Pan et al., 1997; Wang et al., 2000]. However, as previously demonstrated by Wang et al. [2000] and Jian et al. [2008, 2009b], and affirmed by the present study, the earliest age of the Jinshajiang ophiolites (ca. 347$343 \mathrm{Ma}$ ) is apparently younger than that of the Ailaoshan ophiolites (ca. 383-376 Ma, [Jian et al., 2009b]), which indicates a significant difference between timing of initial spreading of the two segments. This may indicate diachronous opening of the branch ocean [e.g., Zhang et al., 1996; Pan et al., 1997; Zhong, 2000].

[37] Despite considerable debate over nature and scale of the Jinshajiang-Ailaoshan ocean [e.g., Mo et al., 1993; Wu et al., 2000; Zhong, 2000; Fan et al., 2010], it is generally believed that this branch of the Paleo-Tethys attained its widest expanse in the Late Carboniferous to Early Permian [Sun and Jian, 2004] and began the process of closure through westward subduction (present-day coordinates), while the main ocean floor was being consumed beneath the Qamdo-Simao Terrane at a east-dipping subduction zone [Wu et al., 2000; Zhong, 2000; Wang et al., 2010] (Figures $8 \mathrm{~b}$ and $8 \mathrm{~d}$ ). Radiometric dating of hornblende from an andesite in the arc created by subduction of the Jinshajiang oceanic slab yielded K/Ar ages of 269-257 Ma [Wang et al., 1999]. The ca. 283 Ma Jiyidu high-Sr/Y tonalite in this study may record an early episode of magmatism triggered by deep-seated partial anatexis of the oceanic slab in the Early Permian, and thus demonstrate that subduction of the Jinshajiang ocean was in operation at that time. Subduction of the Jinshajiang oceanic lithosphere likely facilitated separation of a micro-continental sliver, the Zhongza terrane (Figure 1), from the Yangtze block through opening a smaller Paleo-Tethys branch (the Garze-Litang ocean) along the western Yangtze since the Early Permian time (Figures $9 \mathrm{~b}$ and $9 \mathrm{~d}$ ), as evidenced by recognition of the Garze-Litang ophiolitic belt (Figure 1) [Zhang et al., 1994;
Pan et al., 2003], in which a gabbro yielded a SHRIMP zircon U-Pb age of ca. $292 \mathrm{Ma}$ [Yan et al., 2005].

\section{Conclusions}

[38] Two suites of plagiogranites sampled from the Jinshajiang ophiolitic mélange zone show divergent ages, trace element and isotopic features indicative of distinct geodynamic settings within the Paleo-Tethys.

[39] Petrology and geochemistry of the Dongzhulin trondhjemite suggest a derivation from partial melting of an amphibolitic protolith in response to heat input from an upwelling asthenospheric mantle near the newly formed spreading center. The low-Ti tholeiitic rocks (metamorphosed to amphibolites) that were emplaced during a preceding rift magmatic episode occur as xenoliths within the ophiolitic assemblage and represent a plausible source for the trondhjemite. The Early Carboniferous (ca. $347 \mathrm{Ma}$ ) SHRIMP U-Pb age for this trondhjemite intrusion provides a minimum estimate for the onset of seafloor spreading.

[40] The Jiyidu high-Sr/Y tonalite demonstrates geochemical and isotopic signatures in common with slab meltderived adakites. We propose an origin from melting of the subducted Paleo-Tethys Oceanic crust within the garnetbearing source region for this intrusion. Therefore, its crystallization age (ca. $283 \mathrm{Ma}$ ) indicates ongoing subduction of ocean floor in the Early Permian. This is compatible with a scenario where the Jinshajiang oceanic basin achieved its maximum width in the Late Carboniferous to Early Permian, and then began to shrink by the west-dipping subduction of its oceanic lithosphere, an event possibly accompanied by the opening of a smaller Garze-Litang ocean in its wake.

[41] Acknowledgments. This research was financially supported by projects from the China Natural Science Foundation (40830319 and 40825009), National Basic Research Program of China (2007CB411403), and the Chinese Academy of Science (KZCX1-YW-15-1 and -5) and by the UWA-China Scholarship to J.-W.Z. We thank T. Peng for his help with sample collection; H. Liu and Y. Cai for their support during chemical analyses; A. Zhang, F. Zhang, and Y. Zhang for analyzing zircon Hf isotope; and S. Littmann and J. Cliff for assistance in zircon oxygen isotope analysis. A. Kennedy and I. Fletcher are thanked for discussions on U-Pb data interpretation. The authors acknowledge the facilities, scientific, and technical assistance of the John De Laeter Centre for Isotope Research and the Centre for Microscopy, Characterization and Analysis at UWA. We are grateful to the journal reviewers, J. Schwartz and Y. Dilek, and Associate Editor P. Umhoefer for their constructive comments which greatly improved the manuscript.

\section{References}

Aldiss, D. T. (1981), Plagiogranites from the ocean crust and ophiolites, Nature, 289(5798), 577-578, doi:10.1038/289577a0.

Arth, J. G. (1976), Behavior of trace elements during magmatic processesA summary of theoretical models and their applications, J. Res. U.S. Geol. Surv., 4(1), 41-47.

Barker, F., and J. G. Arth (1976), Generation of trondhjemitic-tonalitic liquids and Archean bimodal trondhjemite-basalt suites, Geology, 4(10), 596-600, doi:10.1130/0091-7613(1976)4<596:GOTLAA > 2.0.CO;2.

Bureau of Geology and Mineral Resources of Yunnan Province (BGMRYP) (1982), Yunnan Geological Map Series: Guxue Sheet (H-47-34), map, Kunming, China.

Bureau of Geology and Mineral Resources of Yunnan Province (BGMRYP) (1985), Yunnan Geological Map Series: Zhongdian Sheet (G-47-4), map, Kunming, China.

Bureau of Geology and Mineral Resources of Yunnan Province (BGMRYP) (1990), Regional Geology of Yunnan Province [in Chinese with English abstract], Geol. Publ., Beijing. 
Bindeman, I. N., J. M. Eiler, G. M. Yogodzinski, Y. Tatsumi, C. R. Stern, T. L. Grove, M. Portnyagin, K. Hoernle, and L. V. Danyushevsky (2005), Oxygen isotope evidence for slab melting in modern and ancient subduction zones, Earth Planet. Sci. Lett., 235(3-4), 480-496, doi:10.1016/j. eps1.2005.04.014

Bonev, N., and G. Stampfli (2009), Gabbro, plagiogranite and associated dykes in the supra-subduction zone Evros Ophiolites, NE Greece, Geol. Mag., 146(1), 72-91, doi:10.1017/S0016756808005396.

Bourdon, E., J.-P. Eissen, M. Monzier, C. Robin, H. Martin, J. Cotten, and M. L. Hall (2002), Adakite-like Lavas from Antisana Volcano (Ecuador): Evidence for Slab Melt Metasomatism Beneath Andean Northern Volcanic Zone, J. Petrol., 43(2), 199-217, doi:10.1093/petrology/43.2.199.

Cocker, J. D., B. J. Griffin, and K. Muehlenbachs (1982), Oxygen and carbon isotope evidence for seawater-hydrothermal alteration of the Macquarie Island ophiolite, Earth Planet. Sci. Lett., 61(1), 112-122, doi:10.1016/0012-821X(82)90043-7.

Defant, M. J., and M. S. Drummond (1990), Derivation of some modern arc magmas by melting of young subducted lithosphere, Nature, 347(6294), 662-665, doi:10.1038/347662a0.

Dilek, Y., and M. F. J. Flower (2003), Arc-trench rollback and forearc accretion: 2. A model template for ophiolites in Albania, Cyprus, and Oman, in Ophiolites in Earth History, edited by Y. Dilek and R. T. Robinson, Geol. Soc. Spec. Publ., 218, 43-68, doi:10.1144/GSL. SP.2003.218.01.04

Dilek, Y., and H. Furnes (2011), Ophiolite genesis and global tectonics: Geochemical and tectonic fingerprinting of ancient oceanic lithosphere, Geol. Soc. Am. Bull., 123(3-4), 387-411, doi:10.1130/B30446.1.

Dilek, Y., and P. T. Robinson (2003), Ophiolites in Earth history: Introduction, in Ophiolites in Earth History, edited by Y. Dilek and R. T. Robinson, Geol. Soc. Spec. Publ., 218, 1-8, doi:10.1144/GSL.SP.2003.218.01.01.

Dilek, Y., and P. Thy (2006), Age and petrogenesis of plagiogranite intrusions in the Ankara mélange, central Turkey, Isl. Arc, 15(1), 44-57, doi:10.1111/j.1440-1738.2006.00522.x

Dixon, S., and M. J. Rutherford (1979), Plagiogranites as late-stage immiscible liquids in ophiolite and mid-ocean ridge suites: An experimental study, Earth Planet. Sci. Lett., 45(1), 45-60, doi:10.1016/0012-821X(79)90106-7.

Drummond, M. S., M. J. Defant, and P. K. Kepezhinskas (1996), Petrogenesis of slab-derived trondhjemite-tonalite-dacite/adakite magmas, in The Third Hutton Symposium on the Origin of Granites and Related Rocks, edited by M. Brown et al., Spec. Pap. Geol. Soc. Am., 315, 205-215.

Eiler, J. M. (2001), Oxygen isotope variations of basaltic lavas and upper mantle rocks, Rev. Mineral. Geochem., 43(1), 319-364, doi:10.2138/ gsrmg.43.1.319.

Eiler, J. M., P. Schiano, N. Kitchen, and E. M. Stolper (2000), Oxygenisotope evidence for recycled crust in the sources of mid-ocean-ridge basalts, Nature, 403(6769), 530-534, doi:10.1038/35000553.

Fan, W., Y. Wang, A. Zhang, F. Zhang, and Y. Zhang (2010), Permian arcback-arc basin development along the Ailaoshan tectonic zone: Geochemical, isotopic and geochronological evidence from the Mojiang volcanic rocks, Southwest China, Lithos, 119(3-4), 553-568, doi:10.1016/j. lithos.2010.08.010.

Fang, N., Q. Feng, S. Zhang, and X. Wang (1998), Paleo-Tethys evolution recorded in the Changning-Menglian Belt, western Yunnan, China, $C$. R Acad. Sci., Ser. IIa, Sci. Terre Planetes, 326(4), 275-282, doi:10.1016/ S1251-8050(97)86818-8.

Feng, Q., M. Ge, D. Xie, Z. Ma, and Y. Jiang (1999), Stratigraphic sequence and tectonic evolution in passive continental margin, Jinshajiang belt, northwestern Yunnan, China, J. China Univ. Geosci., 24(6), 553-557.

Festa, A., G. A. Pini, Y. Dilek, and G. Codegone (2010), Mélanges and mélange-forming processes: A historical overview and new concepts, Int. Geol. Rev., 52(10-12), 1040-1105, doi:10.1080/00206810903557704.

Flagler, P. A., and J. G. Spray (1991), Generation of plagiogranite by amphibolite anatexis in oceanic shear zones, Geology, 19(1), 70-73, doi:10.1130/0091-7613(1991)019<0070:GOPBAA>2.3.CO;2.

Floyd, P. A., M. K. Yaliniz, and M. C. Goncuoglu (1998), Geochemistry and petrogenesis of intrusive and extrusive ophiolitic plagiogranites, Central Anatolian Crystalline Complex, Turkey, Lithos, 42(3-4), 225-241, doi:10.1016/S0024-4937(97)00044-3.

Garrison, J. M., and J. P. Davidson (2003), Dubious case for slab melting in the Northern volcanic zone of the Andes, Geology, 31(6), 565-568, doi:10.1130/0091-7613(2003)031<0565:DCFSMI>2.0.CO;2.

Green, T. H. (1995), Significance of $\mathrm{Nb} / \mathrm{Ta}$ as an indicator of geochemical processes in the crust-mantle system, Chem. Geol., 120(3-4), 347-359, doi:10.1016/0009-2541(94)00145-X.

Gregory, R. T., and H. P. Taylor Jr. (1981), An oxygen isotope profile in a section of Cretaceous oceanic crust, Samail ophiolite, Oman: Evidence for $\delta^{18} \mathrm{O}$ buffering of the oceans by deep ( $\left.>5 \mathrm{~km}\right)$ seawater-hydrothermal circulation at mid-ocean ridges, J. Geophys. Res., 86(B4), 2737-2755, doi:10.1029/JB086iB04p02737

Griffin, W. L., N. J. Pearson, E. Belousova, S. E. Jackson, E. van Achterbergh, S. Y. O'Reilly, and S. R. Shee (2000), The Hf isotope composition of cratonic mantle: LAM-MC-ICPMS analysis of zircon megacrysts in kimberlites, Geochim. Cosmochim. Acta, 64(1), 133-147, doi:10.1016/ S0016-7037(99)00343-9.

Griffin, W. L., X. Wang, S. E. Jackson, N. J. Pearson, S. Y. O’Reilly, $X$. Xu, and X. Zhou (2002), Zircon chemistry and magma mixing, SE China: In-situ analysis of Hf isotopes, Tonglu and Pingtan igneous complexes, Lithos, 61(3-4), 237-269, doi:10.1016/S0024-4937(02)00082-8. Halama, R., T. John, P. Herms, F. Hauff, and V. Schenk (2011), A stable $(\mathrm{Li}, \mathrm{O})$ and radiogenic $(\mathrm{Sr}, \mathrm{Nd})$ isotope perspective on metasomatic processes in a subducting slab, Chem. Geol., 281(3-4), 151-166, doi:10.1016/j.chemgeo.2010.12.001.

Hawkesworth, C. J., and A. I. S. Kemp (2006), Using hafnium and oxygen isotopes in zircons to unravel the record of crustal evolution, Chem. Geol., 226(3-4), 144-162, doi:10.1016/j.chemgeo.2005.09.018.

He, B., Y.-G. Xu, X.-L. Huang, Z.-Y. Luo, Y.-R. Shi, Q.-J. Yang, and S.-Y. $\mathrm{Yu}$ (2007), Age and duration of the Emeishan flood volcanism, SW China: Geochemistry and SHRIMP zircon U-Pb dating of silicic ignimbrites, post-volcanic Xuanwei Formation and clay tuff at the Chaotian section, Earth Planet. Sci. Lett., 255(3-4), 306-323, doi:10.1016/j. eps1.2006.12.021.

Jian, P., D. Liu, and X. Sun (2008), SHRIMP dating of the PermoCarboniferous Jinshajiang ophiolite, southwestern China: Geochronological constraints for the evolution of Paleo-Tethys, J. Asian Earth Sci. 32(5-6), 371-384, doi:10.1016/j.jseaes.2007.11.006.

Jian, P., D. Liu, A. Kroner, Q. Zhang, Y. Wang, X. Sun, and W. Zhang (2009a), Devonian to Permian plate tectonic cycle of the Paleo-Tethys Orogen in southwest China (I): Geochemistry of ophiolites, arc/back-arc assemblages and within-plate igneous rocks, Lithos, 113(3-4), 748-766, doi:10.1016/j.lithos.2009.04.004

Jian, P., D. Liu, A. Kroner, Q. Zhang, Y. Wang, X. Sun, and W. Zhang (2009b), Devonian to Permian plate tectonic cycle of the Paleo-Tethys Orogen in southwest China (II): Insights from zircon ages of ophiolites, arc/back-arc assemblages and within-plate igneous rocks and generation of the Emeishan CFB province, Lithos, 113(3-4), 767-784, doi:10.1016/j. lithos.2009.04.006.

Jiang, Y.-H., S.-Y. Liao, W.-Z. Yang, and W.-Z. Shen (2008), An island arc origin of plagiogranites at Oytag, western Kunlun orogen, northwest China: SHRIMP zircon U-Pb chronology, elemental and Sr-Nd-Hf isotopic geochemistry and Paleozoic tectonic implications, Lithos, 106(3-4), 323-335, doi:10.1016/j.lithos.2008.08.004

Kinny, P. D., and R. Maas (2003), Lu-Hf and Sm-Nd isotope systems in zircon, Rev. Mineral. Geochem., 53(1), 327-341, doi:10.2113/0530327.

Koepke, J., S. Feig, J. Snow, and M. Freise (2004), Petrogenesis of oceanic plagiogranites by partial melting of gabbros: An experimental study, Contrib. Mineral. Petrol., 146(4), 414-432, doi:10.1007/s00410-0030511-9.

Koepke, J., J. Berndt, S. Feig, and F. Holtz (2007), The formation of $\mathrm{SiO}_{2}-$ rich melts within the deep oceanic crust by hydrous partial melting of gabbros, Contrib. Mineral. Petrol., 153(1), 67-84, doi:10.1007/s00410006-0135-y.

Leloup, P. H., R. Lacassin, P. Tapponnier, U. Schärer, D. Zhong, X. Liu, L. Zhang, S. Ji, and P. T. Trinh (1995), The Ailao Shan-Red River shear zone (Yunnan, China), Tertiary transform boundary of Indochina, Tectonophysics, 251(1-4), 3-84, doi:10.1016/0040-1951(95)00070-4.

Li, W.-X., and X.-H. Li (2003), Adakitic granites within the NE Jiangxi ophiolites, South China: Geochemical and Nd isotopic evidence, Precambrian Res., 122(1-4), 29-44, doi:10.1016/S0301-9268(02)00206-1.

Li, X., X. Jiang, Z. Sun, G. Shen, and D. Du (2002), The Collision Orogenic Processes of the Nujiang-Lancangjiang-Jinshajiang Area, SW China [in Chinese with English abstract], 213 pp., Geol. Publ., Beijing.

Ludwig, K. R. (2001a), Squid 1.02: A user manual, Berkeley Geochronological Cent. Spec. Publ. 2, 19 pp, Berkeley Geochronology Cent., Berkeley, Calif.

Ludwig, K. R. (2001b), User's manual for Isoplot/Ex rev.2.49: A geochronological toolkit for Microsoft Excel, Berkeley Geochronological Cent. Spec. Publ. 1a, 55 pp., Berkeley Geochronology Cent., Berkeley, Calif. Macpherson, C. G., S. T. Dreher, and M. F. Thirlwall (2006), Adakites without slab melting: High pressure differentiation of island arc magma, Mindanao, the Philippines, Earth Planet. Sci. Lett., 243(3-4), 581-593, doi:10.1016/j.eps1.2005.12.034.

Martin, H., R. H. Smithies, R. Rapp, J. F. Moyen, and D. Champion (2005), An overview of adakite, tonalite-trondhjemite-granodiorite (TTG), and sanukitoid: Relationships and some implications for crustal evolution, Lithos, 79(1-2), 1-24, doi:10.1016/j.lithos.2004.04.048. 
McCulloch, M. T., R. T. Gregory, G. J. Wasserburg, and H. P. Taylor Jr. (1981), Sm-Nd, $\mathrm{Rb}-\mathrm{Sr}$, and ${ }^{18} \mathrm{O} /{ }^{16} \mathrm{O}$ isotopic systematics in an oceanic crustal section: Evidence from the Samail ophiolite, J. Geophys. Res., 86(B4), 2721-2735, doi:10.1029/JB086iB04p02721.

Metcalfe, I. (1996a), Gondwanaland dispersion, Asian accretion and evolution of eastern Tethys, Aust. J. Earth Sci., 43(6), 605-623, doi:10.1080/ 08120099608728282

Metcalfe, I. (1996b), Pre-Cretaceous evolution of SE Asian terranes, in Tectonic Evolution of Southeast Asia, edited by R. Hall and D. Blundell, Geol. Soc. Spec. Publ., 106, 97-122.

Metcalfe, I. (2006), Palaeozoic and Mesozoic tectonic evolution and palaeogeography of East Asian crustal fragments: The Korean Peninsula in context, Gondwana Res., 9(1-2), 24-46, doi:10.1016/j.gr.2005.04.002.

Mo, X. X., F. X. Lu, and S. Y. Shen (1993), Sanjiang Tethyan Volcanism and Related Mineralization [in Chinese with English abstract], 267 pp. Geol. Publ., Beijing.

Mo, X., J. Deng, and F. Lu (1994), Volcanism and the evolution of Tethys in Sanjiang area, southwestern China, J. Southeast Asian Earth Sci., 9(4), 325-333, doi:10.1016/0743-9547(94)90043-4.

Moyen, J.-F. (2009), High $\mathrm{Sr} / \mathrm{Y}$ and La/Yb ratios: The meaning of the "adakitic signature," Lithos, 112(3-4), 556-574, doi:10.1016/j.lithos.2009.04.001.

Pallister, J. S., and R. J. Knight (1981), Rare-earth element geochemistry of the Samail ophiolite near Ibra, Oman, J. Geophys. Res., 86(B4), 2673-2697, doi:10.1029/JB086iB04p02673.

Pan, G., et al. (1997), Geological-Tectonic Evolution in the Eastern Tethys [in Chinese], Geol. Publ., Beijing.

Pan, G., et al. (2003), Archipelagic Orogenesis, Metallogenic Systems and Assessment of the Mineral Resources Along the Nujiang-LancangjiangJinshajiang Area in Southwestern China [in Chinese with English abstract], Geol. Publ., Beijing.

Peacock, S. M., T. Rushmer, and A. B. Thompson (1994), Partial melting of subducting oceanic crust, Earth Planet. Sci. Lett., 121(1-2), 227-244, doi:10.1016/0012-821X(94)90042-6.

Pearce, J. A., P. D. Kempton, G. M. Nowell, and S. R. Noble (1999), Hf-Nd element and isotope perspective on the nature and provenance of mantle and subduction components in western Pacific arc-basin systems, J. Petrol., 40(11), 1579-1611, doi:10.1093/petrology/40.11.1579.

Pedersen, R. B., and J. Malpas (1984), The origin of oceanic plagiogranites from the karmoy ophiolite, western Norway, Contrib. Mineral. Petrol., 88(1-2), 36-52, doi:10.1007/BF00371410.

Petford, N., and K. Gallagher (2001), Partial melting of mafic (amphibolitic) lower crust by periodic influx of basaltic magma, Earth Planet. Sci. Lett., 193(3-4), 483-499, doi:10.1016/S0012-821X(01)00481-2.

Putlitz, B., A. Matthews, and J. W. Valley (2000), Oxygen and hydrogen isotope study of high-pressure metagabbros and metabasalts (Cyclades, Greece): Implications for the subduction of oceanic crust, Contrib. Mineral. Petrol., 138(2), 114-126, doi:10.1007/s004100050012.

Rapp, R. P., and E. B. Watson (1995), Dehydration melting of metabasalt at 8-32 kbar: Implications for continental growth and crust-mantle recycling, J. Petrol., 36(4), 891-931.

Rapp, R. P., N. Shimizu, M. D. Norman, and G. S. Applegate (1999), Reaction between slab-derived melts and peridotite in the mantle wedge: Experimental constraints at $3.8 \mathrm{GPa}$, Chem. Geol., 160(4), 335-356, doi:10.1016/S0009-2541(99)00106-0.

Richards, J. P., and R. Kerrich (2007), Adakite-like rocks: Their diverse origins and questionable role in metallogenesis, Econ. Geol., 102(4), 537-576, doi:10.2113/gsecongeo.102.4.537.

Samson, S. D., J. D. Inglis, R. S. D'Lemos, H. Admou, J. Blichert-Toft, and K. Hefferan (2004), Geochronological, geochemical, and Nd-Hf isotopic constraints on the origin of Neoproterozoic plagiogranites in the Tasriwine ophiolite, Anti-Atlas orogen, Morocco, Precambrian Res., 135(1-2), 133-147, doi:10.1016/j.precamres.2004.08.003.

Schwartz, J. J., K. Johnson, E. A. Miranda, and J. L. Wooden (2011), The generation of high $\mathrm{Sr} / \mathrm{Y}$ plutons following Late Jurassic arc-arc collision, Blue Mountains province, NE Oregon, Lithos, 126(1-2), 22-41, doi:10.1016/j.lithos.2011.05.005.

Shaw, D. M. (1970), Trace element fractionation during anatexis, Geochim Cosmochim. Acta, 34(2), 237-243, doi:10.1016/0016-7037(70)90009-8.

Smithies, R. H., and D. C. Champion (2000), The Archaean high-Mg diorite suite: Links to tonalite-trondhjemite-granodiorite magmatism and implications for early Archaean crustal growth, J. Petrol., 41(12), 1653-1671, doi:10.1093/petrology/41.12.1653

Stakes, D. S., and H. P. Taylor (2003), Oxygen isotope and chemical studies on the origin of large plagiogranite bodies in northern Oman, and their relationship to the overlying massive sulphide deposits, in Ophiolites in Earth History, edited by Y. Dilek and R. T. Robinson, Geol. Soc. Spec. Publ., 218, 315-351, doi:10.1144/GSL.SP.2003.218.01.17.

Stakes, D. S., H. P. Taylor, and R. L. Fisher (1984), Oxygen-isotope and geochemical characterization of hydrothermal alteration in ophiolite complexes and modern oceanic crust, in Ophiolites and Oceanic Lithosphere, edited by I. G. Gass, S. J. Lippard, and A. W. Shelton, Geol. Soc. Spec. Publ., 13, 199-214, doi:10.1144/GSL.SP.1984.013.01.17.

Staudigel, H., G. R. Davies, S. R. Hart, K. M. Marchant, and B. M. Smith (1995), Large scale isotopic Sr, Nd and O isotopic anatomy of altered oceanic crust: DSDP/ODP sites417/418, Earth Planet. Sci. Lett., 130(1-4), 169185, doi:10.1016/0012-821X(94)00263-X

Stern, C. R., and R. Kilian (1996), Role of the subducted slab, mantle wedge and continental crust in the generation of adakites from the Andean Austral Volcanic Zone, Contrib. Mineral. Petrol., 123(3), 263-281, doi:10.1007/s004100050155.

Stern, R. A. (2001), A new isotopic and trace-element standard for the ion microprobe: Preliminary TIMS and electron microprobe data, Rep. 14 11 pp., Geol. Surv. of Can., Ottawa, doi:10.4095/212668.

Sun, S. S., and W. F. McDonough (1989), Chemical and isotopic systematics of oceanic basalts: Implications for mantle composition and processes, in Magmatism in the Ocean Basins, edited by A. D. Saunders and M. J. Norry, Geol. Soc. Spec. Publ., 42, 313-345, doi:10.1144/GSL. SP.1989.042.01.19.

Sun, X., and P. Jian (2004), The Wilson cycle of the Jinshajiang PaleoTethys Ocean, in western Yunnan and Sichuan Provinces [in Chinese with English abstract], Geol. Rev. (Beijing, China), 50(4), 343-350.

Sun, X., Z. Yang, M. Zhang, Z. Nie, D. Liang, and B. Zhang (1999), On the stratigraphy and tectonic evolution of the Jinsha River Paleo-Tethys orogenic belt in NW Yunnan, J. Changchun Univ. Sci. Technol., 29(1), 20-24.

Valley, J. W. (2003), Oxygen isotopes in zircon, Rev. Mineral. Geochem., 53(1), 343-385, doi: $10.2113 / 0530343$

Valley, J. W., et al. (2005), 4.4 billion years of crustal maturation: Oxygen isotope ratios of magmatic zircon, Contrib. Mineral. Petrol., 150(6), 561580, doi:10.1007/s00410-005-0025-8

Wang, L., G. Pan, D. Li, Q. Xu, and S. Lin (1999), The spatio-temporal framework and geological evolution of the Jinshajiang arc-basin systems, Dizhi Xuebao, 73(3), 206-218

Wang, Q., F. McDermott, J.-F. Xu, H. Bellon, and Y.-T. Zhu (2005), Cenozoic K-rich adakitic volcanic rocks in the Hohxil area, northern Tibet: Lower-crustal melting in an intracontinental setting, Geology, 33(6), 465-468, doi:10.1130/G21522.1.

Wang, X., I. Metcalfe, P. Jian, L. He, and C. Wang (2000), The JinshajiangAilaoshan Suture Zone, China: Tectonostratigraphy, age and evolution, J. Asian Earth Sci., 18(6), 675-690, doi:10.1016/S1367-9120(00)00039-0.

Wang, Y., A. Zhang, W. Fan, T. Peng, F. Zhang, Y. Zhang, and X. Bi (2010), Petrogenesis of late Triassic post-collisional basaltic rocks of the Lancangjiang tectonic zone, southwest China, and tectonic implications for the evolution of the eastern Paleotethys: Geochronological and geochemical constraints, Lithos, 120(3-4), 529-546, doi:10.1016/j. lithos.2010.09.012.

Wei, Q., S. Shen, X. Mo, and F. Lu (2003), Characteristics of Nd-Sr-Pb isotope systematics of the source in Paleo-Tethyan volcanic rocks in the Sanjiang Area [in Chinese with English abstract], J. Mineral. Petrol., 23(1), 55-60.

Williams, I. S. (1998), U-Th-Pb geochronology by ion microprobe, in Applications of Microanalytical Techniques to Understanding Mineralizing Processes, Rev. Econ. Geol., vol. 7, edited by M. A. McKibben, W. C. Shanks, and W. I. Ridley, pp. 1-35, Soc. of Econ. Geol., Littleton, Colo. Wu, G., X. Wang, D. Zhong, Z. Nie, D. Liang, and F. He (2000), Two arc volcanics suites of Permian-Early Triassic bordering Sichuan, Yunnan and Xizang, China [in Chinese with English abstract], Sci. Geol. Sin. 35(3), 350-362

Wu, H., C. A. Boulter, B. Ke, D. A. V. Stow, and Z. Wang (1995), The Changning-Menglian suture zone; a segment of the major CathaysianGondwana divide in Southeast Asia, Tectonophysics, 242(3-4), 267-280, doi:10.1016/0040-1951(94)00210-Z

$\mathrm{Xu}$, J.-F., and P. R. Castillo (2004), Geochemical and Nd-Pb isotopic characteristics of the Tethyan asthenosphere: Implications for the origin of the Indian Ocean mantle domain, Tectonophysics, 393(1-4), 9-27, doi:10.1016/j.tecto.2004.07.028.

Yan, Q., et al. (2005), Opening of the Tethys in southwest China and its significance to the breakup of East Gondwanaland in late Paleozoic: Evidence from SHRIMP U-Pb zircon analyses for the Garzê ophiolite block, Chin. Sci. Bull., 50(3), 256-264.

Yogodzinski, G. M., R. W. Kay, O. N. Volynets, A. V. Koloskov, and S. M. Kay (1995), Magnesian andesite in the western Aleutian Komandorsky region: Implications for slab melting and processes in the mantle wedge, Geol. Soc. Am. Bull., 107(5), 505-519, doi:10.1130/0016-7606(1995)107< 0505:MAITWA >2.3.CO;2.

Zhang, Q., Z. Kuiwu, and D. Li (1992), Mafic-Ultramafic Rocks in Hengduan Mountains Region [in Chinese with English abstract], Sci. Press, Beijing. 
Zhang, Q., D. Zhou, D. Zhao, Z. Huang, S. Han, X. Jia, and J. Dong (1994), Ophiolites of the Hengduan Mountains, China: Characteristics and tectonic settings, J. Southeast Asian Earth Sci., 9(4), 335-344, doi:10.1016/0743-9547(94)90044-2.

Zhang, Q., D. Zhou, D. Zhao, X. Peng, W. Luo, and X. Liu (1996), Wilson cycle of the Paleo-Tethyan Orogenic Belt in western Yunnan: Record of magmatism and discussion on mantle processes [in Chinese with English abstract], Acta Petrol. Sin., 12(1), 17-28.

Zhong, D. (2000), Paleotethysides in West Yunnan and Sichuan, China, 248 pp., Sci. Press, Beijing.

Zi, J.-W., W. Fan, Y. Wang, T. Peng, and F. Guo (2008), Geochemistry and petrogenesis of the Permian mafic dykes in the Panxi region, SW China, Gondwana Res., 14(3), 368-382, doi:10.1016/j.gr.2008.02.008.

Zi, J.-W., W.-M. Fan, Y.-J. Wang, P. A. Cawood, T.-P. Peng, L.-H. Sun, and Z.-Q. Xu (2010), U-Pb geochronology and geochemistry of the Dashibao Basalts in the Songpan-Ganzi Terrane, SW China, with implications for the age of Emeishan volcanism, Am. J. Sci., 310(9), 1054-1080, doi:10.2475/09.2010.11.

Zi, J.-W., P. A. Cawood, W.-M. Fan, E. Tohver, Y.-J. Wang, and P. C. McCuaig (2011), U-Pb age, geochemcal and Hf-O isotopic constraints on magma source of the I-type calc-alkaline Baimaxueshan Batholith (SW China): Implications for crustal recycling at a convergent margin, Mineral. Mag., 75(3), 2282.

Zi, J.-W., P. A. Cawood, W.-M. Fan, E. Tohver, Y.-J. Wang, and T. C. McCuaig (2012), Generation of Early Indosinian enriched mantle-derived granitoid pluton in the Sanjiang Orogen (SW China) in response to closure of the Paleo-Tethys, Lithos, 140-141, 166-182, doi:10.1016/j. lithos.2012.02.006.

P. A. Cawood, Department of Earth Sciences, University of St. Andrews, Irvine Bldg., North Street, St. Andrews KY16 9AL, UK.

W.-M. Fan and Y.-J. Wang, State Key Laboratory of Isotope Geochemistry, Guangzhou Institute of Geochemistry, Chinese Academy of Sciences, 511 Kehua St., Guangzhou, Guangdong 510640, China.

E. Tohver and J.-W. Zi, School of Earth and Environment, University of Western Australia, 35 Stirling Hwy., Crawley, WA 6009, Australia. (zijianw@gmail.com) 